\title{
Effect of Reward and Punishment on Employee Performance
}

Eko Septian Dymastara ${ }^{1}$

${ }^{1}$ Proposal Penelitian Prodi Manajemen UM Bengkulu 2020

\begin{abstract}
This study aims to find out what factors influence employee performance including: (1) Effect of Reward on the performance of employees of PT. Sandabi Indah Lestari North Bengkulu, (2) Effect of Punishment on the performance of the employees of PT. Sandabi Indah Lestari North Bengkulu. (3)

This research is a survey research with quantitative approach. The sample of this study were employees of PT. Sandabi Indah Lestari Bengkulu Utara, which amounted to 96 employees by taking a minimum sample of employees. Data collection using a questionnaire while data analysis was performed using multiple regression analysis.
\end{abstract}

\section{Keywords : Reward, Punishment and employee performance}

\section{BAB 1 \\ PENDAHULAN}

\subsection{Latar Belakang}

Dalam era globlisasi seperti sekarang ini persaingan dan kompetisi semakin hari semakin ketat dan luas. Seringkali dengan perkembangan tersebut, masalah yang dialami perusahaan semakin kompetitif karena perusahaan akan menghadapi lebih banyak pesaing dan tantangan. Namun perusahaan dituntut untuk dapat meningkatkan hasil produksi CPO (Crude Palm Oil) sesuai dengan target, dengan ini maka di lakukan peningkatkan kualitas sumber daya manusia (SDM) menjadi lebih baik dan memiliki mutu yang bagus. Manajemen sumber daya manusia merupakan suatu perencanaan, pengorganisasian, pengkoordinasian, pelaksanakan, dan pengawasan terhadap pengadaan, pengembangan, pemberian balas jasa, 
pengintergrasian, pemeliharaan, dan pemisahan tenaga kerja dalam rangka mencapai tujuan organisasi. Kerena hal tersebut sumber daya manusia menjadi aspek yang sangat penting bagi sebuah organisasi atau perusahaan, manusia selalu berperan aktif dan dominan dalam setiap organisai karena manusia yang menjadi perencana, pelaku dan penentuan terwujudnya tujuan peruasahaan.

Keberhasilan atau tidaknya suatu perusahaan dalam mencapai tujuan yang telah ditetapkan oleh perusahaan sebelumnya sangat tergantung pada kemampuan dengan sumber daya manusia dalam melaksanakan tugas yang diberikan. Apabila sumber daya manusianya berjalan efektif maka perusahaan akan berjalan sesuai target yang diberikan. Setiap perusahaan selalu mengharapkan karyawan mempunyai prestasi agar dapat meningkatkan perusahaan.

Perusahaan harus melakukan upaya pemberdayaan sumber daya manusia yang bertujuan untuk meningkatkan kinerja. Kinerja merupakan perilaku nyata ditampilkan setiap orang sebagai preserta kerja yang dihasilkan oleh karyawan sesuai dengan perannya (Rivai, 2015). Kinerja perusahaan juga akan meningkat salah satunya melalui penerapan rewerd dan punishement. Keduanya memiliki peran untuk meningkatkan kualitas kerja dan lebih bertanggung jawab terhadap tugas yang diberikan oleh perusahaan.

Menurut Kadarisman (2012) Asmawi, M. (2017) Reward adalah semua bentuk return baik finansial maupun non finasial yang diterima 
karyawan karena jasa yang disumbangkan ke perusahaan. Pemberian reward atau penghargaan kepada karyawan yang berprestasi akan memberikan motivasi kepada karyawan untuk lebih meningkatkan kinerja karyawan. Dengan karyawan yang semakin meningkatkan kinerja maka akan meningkatkan laba perusahaan, dengan laba perusahaan yang tinggi akan meningkatkan kesejahteraan karyawannya dan perusahaan dengan karyawan akan sama-sama mendapatkan keuntungan.

Perusahaan juga harus menerapakan sanksi atau punishment kepada karyawan yang malas dan lalai dalam berkerja. Sanksi atau punishment adalah hukuman yang diberikan karena adanya pelangaran yang di lakukan oleh karyawan. Punishment jika digunakan secara efektif dapat menekan perilaku pelangaran dalam perusahaan, dengan kata lain punishment sebaiknya diberikan setelah melalui pertimbangan yang cermat dan objektif dari semua aspek yang relevan dengan situsi yang ada dalam perusahaan.

Salah satu peran penting dari punishment adalah memilihara kedisiplinan karyawan (Hasibuan 2004). Semakin berat punishment akan membuat karyawan merasa takut untuk melanggar aturan perusahaan, serta akan membuat sikap dan perilaku indisipliner berkurang. Akan tetapi, punishment harus diterapkan berdasarkan pertimbangan yang logis, masuk akal dan telah diinformsikan secara jelas kepada karyawan. Punishment seharusnya diterapkan tidak terlalu ringan maupun terlalu berat karena punishment bersifat mendidik dan menjadi alat motivasi untuk memelihara 
kedisiplinan dalam organisasi dan supaya karyawan juga tidak terlalu menyepelekan pekerjaan yang sudah di berikan.

Pemberian reward dan punishment ini harus dilakukan secara relevan dan dapat diukur, sehingga nantinya karyawan mengetahui indikator apa yang digunakan pada saat penilaian kepada para karyawan yang mendapatkan reward. Dengan demikian, hal ini nantinya akan memotivasi karyawan lainnya untuk melakukan pekerjaan dengan baik agar mendapatkan reward yang sama atau bahkan lebih dari yang didapat rekan kerja yang sebelumnya. Perusahaan tidak bisa memberikan reward dan punishment hanya berdasarkan suka atau tidak suka.

Pemberian reward dan punishment yang tidak adil akan menyebabkan kecemburuan sosial yang timbul diantara karyawan sehingga akan memicu hubungan kerja yang negatif dan tentunya berdampak pada kinerja karyawan. Pemberian reward dan punishment sangat penting dalam memotivasi kinerja karyawan didalam perusahaan. Karena melalui pemberian reward dan punishment kinerja karyawan akan menjadi lebih berkualitas dan bertanggung jawab dengan tugas yang diberikan. Dengan ini maka karyawan dapat meningkatkan kinerjanya, sehingga dapat memacu karyawan untuk memberikan hasil yang maksimal kepada perusahaan.

Pemberian reward dan punishment bagi karyawan pada PT. Sandabi Indah Lestri Bengkulu Utara menjadi perhatian penuh bagi manajerial, demi untuk menjaga dan memenuhi standart kerja PT. Sandabi Indah Lestri Bengkulu Utara sekaligus untuk bergerak aktif meningkatkan kinerja 
karyawannya guna mencapai dan memenuhi target yang telah ditentukan oleh perusahaan. Bagi beberapa karyawan yang belum terbiasa dengan sistem pengawasan ketat dengan penerapan reward dan punishment, kebanyakan mereka merasa tertekan dan beberapa karyawan lainnya justru menganggap itu sebagai motivasi untuk meningkatkan kualitas kerja mereka pada PT. Sandabi Indah Lestri Bengkulu Utara.

Kondisi tersebut mengharuskan PT. Sandabi Indah Lestri Bengkulu Utara dapat menerapkan strategi yang tepat untuk meningkatkan kualitas sumber daya manusia agar mampu bersaing dengan pasar global serta dapat bekerja sesuai target guna memenuhi permintaan pasar. PT Sandabi Indah Lestri Bengkulu Utara. Menyadari bahwa untuk memaksimalkan kinerja karyawannya, maka diperlukan pemberian reward dan punishment yang baik dan konsisten. Penerapan sistem yang baik akan menyebabkan perusahaan dapat memaksimalkan setiap potensi yang dimiliki oleh setiap sumber daya manusia agar mampu bekerja secara optimal sesuai dengan standar yang telah ditentukan oleh PT. Sandabi Indah Lestri Bengkulu Utara.

Dari observasi yang dilakukan di PT. Sandabi Indah Lestari Bengkulu Utara melalui wawancara dengan narasumber Bapak Lamhot Sianturi, S.H sebagai Personalia \& GA pada tanggal 05 Februari 2020 jam 14:20 WIB ditemukan permasalahan yang ada dalam perusahaan yaitu tingkat kinerja karyawan yang kurang baik dikarenakan tidak adanya pemberian reward kepada karyawan yang berprestasi dan permasalahan lainnya adalah 
kurangnya pemberian punishment kepada karyawan yang malas berkerja, lalai dalam berkerja serta karyawan meremehkan sanksi yang ada dalam perusahaan. Karena hal itu akan menyebabkan kinerja karyawan terganggu. Dengan adanya pemberian reward dan punishment yang dapat meningkatkan kinerja karyawan yang dapat meningkatkan laba perusahaan dan juga meningkatkan kesejahteraan karyawan yang ada di perusahaan. selain reward pemberian punishment kepada karyawan yang sesuai dengan kesalahan yang dilakukan oleh karyawan tersebut. Agar apa yang diharapkan dapat meningkatkan kinerja karyawan dan tidak akan mengulangi kesalahannya lagi.

Berdasarkan latar belakang di atas maka penulis tertarik untuk melakukan penelitian dengan judul "Pengaruh Reward Dan Punishment Terhadap Kinerja Karyawan Pada PT. Sandabi Indah Lestri Bengkulu Utara".

\subsection{Identifikasi Masalah}

Dari beberapa uraian yang dikemukakan pada latar belakang, maka dapat diidentifikasi masalah - masalah sebagai berikut :

1. Reward kepada karyawan PT. Sandabi Indah Lestri Bengkulu Utara masih sangat kurang.

2. Punishment pada PT. Sandabi Indah Lestari Bengkulu Utara belum optimal. 


\subsection{Pembatasan Masalah}

Agar penelitian ini tidak menyimpang dari pokok permasalahan maka peneliti hanya membatasi masalah pada pengaruh reward dan punishment terhadap kinerja karyawan pada PT. Sandabi Indah Lestari Bengkulu Utara.

\subsection{Rumusan Masalah}

Berdasarkan pada latar belakang yang dikemukakan diatas, maka secara terperinci masalah-masalah yang akan diteliti adalah rewerd dan punishment dapat berpengaruh terhadap kinerja karyawan sebagai berikut:

1. Apakah reward berpengaruh kepada kinerja karyawan pada PT. Sandabi Indah Lesati Bengkulu Utara?

2. Apakah punishment berpengaruh kepada kinerja karyawan PT. Sandabi Indah Lestari Bengkulu Utara?

3. Apakah reward dan punishment berpengaruh terhadap kinerja karyawan PT. Sandabi Indah Lestari Bengkulu Utara?

\subsection{Tujuan Penelitian}

Berdasarkan latar belakang masalah dan untuk menjawab permasalahan yang telah dirumuskan diatas, penelitian ini bertujuan:

1. Untuk mengetahui pengaruh variabel reward terhadap kinerja karyawan PT. Sandabi Indah Lestari Bengkulu Utara.

2. Untuk mengetahui pengaruh variabel punishment terhadap kinerja karyawan pada PT. Sandabi Indah Lestari Bengkulu Utara. 
3. Untuk mengetahui pengaruh rewerd dan punishment terhadap kinerja karyawan pada PT. Sandabi Indah Lestari Bengkulu Utara.

\subsection{Manfaat Penelitian}

Hasil penelitian tentang pengaruh pemberian rewerd dan punishment terhadap kinerja PT. Sandabi Indah Lestari Bengkulu Utara adalah sebagai berikut:

1. Bagi PT. Sandabi Indah Lestari Bengkulu Utara

Hasil penelitian ini diharapkan bisa menjadi bahan pertimbangan dan masukan bagi PT. Sandabi Indah Lestari Bengkulu Utara dalam upaya meningkatkan kinerja karyawan di masa yang akan datang.

2. Bagi Akademik

Hasil penelitian ini dapat digunakan sebagai bahan penelitian lebih lanjut guna untuk menambah wawasan dan pengetahuan tentang pemberian reward dan punishment terhadap kinerja karyawan PT. Sandabi Indah Lestari Bengkulu Utara.

3. Bagi Peneliti

Peniliti diharapkan dapat menambah referensi dan wacana untuk mengembangkan ilmu pengetahuan tentang manajemen sumber daya manusia khususnya yang berhubungan dengan pengaruh pemberian reward dan punishment terhadap kinerja karyawan. 


\section{BAB II}

\section{STUDI PUSTAKA}

\subsection{Deskripsi Konseptual}

\subsubsection{Kinerja}

Sebagai fungsi dasar dalam kinerja adalah motivasi dan kemampuan. Untuk menyelesaikan tugas atau pekerjaan seseorang sepatutnya memiliki derajat kesediaan dan tingkat kemampuan tertentu. Kesediaan dan keterampilan seseorang tidaklah cukup efektif untuk mengerjakan sesuatu tanpa pemahaman yang jelas tentang apa yang akan dikerjakan dan bagaimana mengerjakannya.

Kinerja atau performance merupakan gambaran mengenai tingkat pencapaian pelaksanaan suatu program kegiatan atau kebijakan dalam mewujudkan visi, misi, tujuan dan sasran organisasi yang dituangkan melalui perencanaan strategis organisasi. (Moeheriono, 2014, Onsardi, O., 2019). Menurut Amstrong dan Baron dalam Wibowo (2016:2) mengemukakan bahwa “ Kinerja merupakan hasil pekerjaan yang mempunyai hubungan kuat dengan tujuan strategis organisasi, kepuasan konsumen dan memberikan kontribusi ekonomi." Sedangkan menurut Gibson, Ivancevich Donnelly, dan Konopaske dalam Wibowo (2016:2) menyatakan bahwa "Kinerja adalah hasil dari pekerjaan yang berkaitan dengan tujuan organisasi seperti kuaitas, efisiensi dan kriteria lain dari efektivitas". Menurut Sedarmayanti (2017:463) mengemukakan bahwa "Kinerja adalah hasil kerja yang dicapai oleh seseorang/kelompok orang 
dalam suatu organisasi sesuai dengan wewenang dan tanggung jawab masing-masing dalam rangka mencapai tujuan organisasi yang bersangkutan, secara legal, tidak melanggar hukum, dan sesuai moral dan etika". Dan menurut Veithzal Rivai dan Ella Jauvani (2010:548) menyatakan bahwa "Kinerja merupakan perilaku nyata yang ditampilkan setiap orang sebagai prestasi kerja yang dihasilkan oleh karyawan sesuai dengan perannya dalam perusahaan.” Lebih lanjut bahwa kinerja itu adalah unjuk kerja karyawan pada suatu perusahaan yang merupakan pencerminan loyalitas mereka dimana mereka bekerja (Anjani, R., 2019, Onsardi, O., 2018, Juita, R., 2020, Gayatri, G. D., 2020)

Dari beberapa pendapat diatas penulis menarik kesimpulan bahwa kinerja dapat diartikan sebagai suatu hasil kerja atau pencapaian prestasi kerja seorang pegawai dalam melaksanakan tugasnya sesuai dengan wewenang dan tanggungjawab masing-masing yang berkaitan dengan tujuan strategis organisasi, kepuasan konsumen dan memberikan kontribusi ekonomi.

\subsubsection{Indikator Kinerja}

Wibowo (2016:173) menyatakan bahwa indikator atau ukuran kinerja untuk seorang karyawan ialah sebagai berikut :

1. Kuantitas, dinyatakan dalam bentuk jumlah output, atau persentase antara output aktual dengan output yang menjadi target. 
2. Kualitas, dinyatakan dalam bentuk pengawasan kualitas yang bervariasi di luar batas, jumlah keluhan yang masih dalam batas yang dapat dipertimbangkan untuk ditoleransi.

3. Produktivitas, diukur sebagai output per pekerja.

4. Ketepatan waktu, dinyatakan dalam bentuk pencapaian batas waktu pengiriman, jumlah unit yang dapat diselesaikan tepat waktu.

5. Pengawasan biaya, sebagai biaya perunit produksi, variasi upah buruh langsung/ tidak langsung

6. Pasilitas, yaitu peralatan atau sarana dan prasarana yang mendukung dalam melaksanakan pekerjaan, (Onsardi, O., 2020).

Sedangkan menurut Sudarmanto (2009:79), mengemukakan bahwa indikator kinerja untuk seorang karyawan ialah sebagai berikut:

1. Kualitas, yaitu terkait dengan memproduksikan barang dan jasa yang dihasilkan dalam memenuhi maksud dan tujuan

2. Kuantitas, yaitu terkait dengan kemampuan dalam menghasilkan produk barang dan jasa

3. Ketepatan waktu/time liness, yaitu berkaitan dengan waktu yang diperlukan dalam menyelesaikan aktivitas atau menghasilkan produk.

4. Kerja sama dengan orang lain dalam bekerja. Dalam suatu kinerja terdapat faktor-faktor yang dapat mempegaruhi kinerja seseorang baik yang bersifat positif maupun negatif.

Prestasi atau kinerja adalah catatan tentang hasil yang diperoleh dari fungsi-fungsi pekerjaan tertentu atau kegiatan selama kurun waktu 
tertentu. Menurut Mangkunegara (2013) hal yang perlu diperhatikan oleh manajer sumber daya manusia dalam kinerja karyawan dengan indikator :

1. Kualitas kerja yaitu seberapa baik karyawan melakukan pekerjaannya.

2. Kuantitas kerja yaitu seberapa lama karyawan melakukan pekerjaannya dalam satu harinya.

3. Pelaksanaan tugas yaitu seberapa jauh karyawan dapat menyelesaikan pekerjaannya dengan akurat atau tanpa kesalahan.

4. Tanggung jawab atas pekerjaan yaitu kesadaran akan pekerjaan yang diberikan kepada karyawan dalam melaksanakan pekerjaan.

\subsubsection{Faktor - Faktor Yang Mempengaruhi Kinerja}

Anwar Prabu Mangkunegara (2015:67) menyatakan bahwa faktor yang mempengaruhi kinerja kerja adalah:

1. Faktor Kemampuan

Secara psikologis, kemampuan (Ability) dan kemampuan reality $($ Knowledge + Skill). Artinya, pegawai yang memiliki IQ rata - rata (IQ 110 - 120) dengan pendidikan yang memadai untuk jabatannya dengan terampil dalam mengerjakan perkerjaannya sehari - hari, maka ia akan lebih mudah mencapai prestasi kerja yang diharapkan. Oleh karena itu, pegawai perlu ditempatkan pada pekerjaan yang sesuai dengan keahliannya (the right man on the right place, the right man on the rightjob).

2. Faktor Motivasi 
Motivasi terbentuk dari sikap seorang pegawai dalam menghadapi situasi (situation) kerja. Motivasi merupakan kondisi yang menggerakkan diri pengwai terarah untuk mencapai tujuan kerja.

\subsubsection{Pengertian Reward}

Reward merupakan salah satu metode untuk memotivasi seseorang untuk melakukan kebaikan dan meningkatkan prestasinya. Reward dapat diartikan pula sebagai sebuah bentuk apresiasi kepada suatu prestasi tertentu yang diberikan, baik oleh dan dari perorangan. Sebagai faktor pemicu keberhasilan suatu perusahaan, pemberian penghargaan (reward) memegang peranan penting. Seringkali dalam proses dalam mencapai tujuannya, perusahaan terkadang tidak tepat waktu atau kurang berhasil dilaksanakan. Dengan adanya reward bagi karyawan yang konsisten dan berhasil mencapai target yang telah diberikan, maka akan memacu karyawan tersebut untuk berbuat lebih baik lagi bagi organisasinya.

Dengan demikian dapat dikatakan bahwa reward adalah suatu cara yang digunakan oleh seseorang atau organisasi untuk memberikan apresiasi kepada individu atau organisasi yang telah berhasil melakukan pekerjaan dengan baik dan berprestasi, sehingga akan dapat memberikan motivasi positif untuk individu atau organisasi untuk kembali mengerjakan pekerjaan tersebut dengan baik.

Dalam organisasi, suatu penghargaan dalam bentuk material atau non material yang diberikan oleh pihak pimpinan organisasi perusahaan kepada karyawan bertujuan agar memotivasi mereka bekerja lebih keras 
dan berprestasi dalam mencapai tujuan-tujuan perusahaan atau organisasi (Febrianti, Al Musadieq, \& Prasetya, 2014). Menurut Kadarisman (2012:122) Reward adalah semua bentuk return baik finansil maupun non finasial yang diterima karyawan karena jasa yng disumbangkan ke perusahaan.

Menurut Matteson dalam Koencoro (Koencoro, 2013) reward dibagi menjadi dua jenis yaitu reward extrinsik dan reward intrinsik. Penghargaan ekstrinsik (ekstrinsic rewards) adalah suatu penghargaan yang datang dari luar diri orang tersebut. Penghargaan ekstrinsik terdiri dari penghargaan finansial yaitu gaji, tunjangan, bonus/insentif dan penghargaan non finansial yaitu penghargaan interpersonal serta promosi. Penghargaan intrinsik (intrinsic rewards) adalah suatu penghargaan yang diatur oleh diri sendiri yang terdiri dari Penyelesaian (completion), Pencapaian (achievement), dan Otonomi.

Dari beberapa pendapat para ahli tersebut dapat disimpulkan bahwa pemberian reward atau penghargaan merupakan salah satu cara atau metode untuk meningkatkan motivasi seseorang atau organisasi supaya bisa terus melakukan hal yang baik dan berprestasi. Sehingga nantinya akan mendapatkan balas jasa berupa penghargaan, baik berupa materil maupun non materil.

\subsubsection{Indikator Reward}

Menurut siagian (2016), indikator reward adalah sebagai berikut

1. Pekerjaan itu sendiri 
2. Upah

3. Peluang promosi

4. Pengawasan

5. Rekan kerja

Menurut Kadarisman (2012 : 122), indikator reward adalah sebagai berikut:

1. Gaji

2. Upah

3. Insentif

4. Tujangan

5. Pengharaan interpersonal

6. Promosi

Menurut Mahmudi (2013:187), indikator reward adalah sebagai berikut:

1. Gaji dan bonus

Gaji merupakan komponen reward yang sangkat penting bagi karyawan gaji dalam hal ini meliputi gaji pokok dan tambahan kompensasi keuangan berupa bonus dan pemberian saham (stock option atau stock grant). Pemberian gaji dan tambahan kompensasi berupa bonus dapat memotivasi karyawan untuk terus meningkatkan kinerjanya. Reward terhdap kinerja yang tinggi dapat diberikan dalam bentuk kenaikan gaji dan pemberian bonus.

2. Kesejahteraan 
Kesejahteraan dapat diukur nilainya. Berbagai program Kesejahteraan karyawan yang ditawarkan organisasi sebagai bentuk pemberian reward atau presentasi kinerja misalnya, dalam bentuk tunjangan (tunjangan kesehatan, tunjangan pendidikan anak, tunjangan keluarga dan tunjangan hari tua) dan kesejahteran rohani (liburan paket ibadah dan sebagainya).

3. Pengembangan karier

Pengembangan karier merupakan prospek dimasa yang akan datang. Pengembngan karir ini penting diberikan bagi karyawan yang memiliki prestasi yang memuaskan agar nilai pegawai itu lebih tinggi sehingga mampu memberikan kinerja yang lebih baik lagi dimasa yang akan datang.

4. Penghargaan psikologis dan sosial

Penghargaan psikologis dan sosial lebih sulit diukur nilai finansialnya, namun nilai penghargaan ini penting bagi karyawan merasa ingin diterima dan dihargai atas hasil kerjanya.

\subsubsection{Jenis - Jenis Reward}

Menurut Wilson Matteson dalam Koencoro (2013:2), menyatakan bahwa reward dibagi menjadi dua jenis yaitu:

1. Penghargaan extrinsik (ekstrinsic rewards)

Penghargaan extrinsik adalah suatu penghargaan yang datang dari luar diri orang tersebut.

a. Penghargaan finansial: 
1. Gaji adalah balas jasa dalam bentuk uang yang diterima karyawan sebagai konsekuensi dari kedudukanya sebagai seorang karyawan yang memberikan sumbangan tenaga dan pikiran dalam mencapai tujuan perusahaan atau dapat dikatakan sebagai bayaran tetap yang diterima seseorang dari sebuahperusahaan

2. Tunjangan karyawan seperti dana pensiun, perawatan di rumah sakit dan liburan. Pada umumnya merupakan hal yang tidak berhubungan dengan kinerja karyawan, akan tetapi didasarkan pada senioritas atau catatan kehadiran.

3. Bonus/ Insentif adalah tambahan - tambahan imbalan di atas atau di luar gaji/ upah yang diberikan organisasi

b. Penghargaan non finansial:

1. Penghargaan interpersonal

Atau biasa yang disebut dengan penghargaan antar pribadi, manajer memiliki sejumlah kekuasaan untuk mendistribusikan penghargaan interpersonal, seperti status danpengakuan

2. Promosi

Manajer menjadikan penghargaan promosi sebagai usaha untuk menempatkan orang yang tepat pada pekerjaan yang tepat. Kinerja jika diukur dengan akurat, sering kali memberikan pertimbangan yang signifikan dalam alokasi penghargaan promosi

2. Penghargaan extrinsik (ekstrinsic rewards) 
Penghargaan intrinsik adalah suatu penghargaan yang diatur oleh diri sendiri yang yang terdiri.

a. Penyelesaian (completion)

Kemampuan memulai dan menyelesaikan suatu pekerjaan atau proyek merupakan hal yang sangat penting bagi sebagian orang. Orang-orang seperti ini menilai apa yang mereka sebut sebagai penyelesaian tugas. Beberapa orang memiliki kebutuhan untuk menyelesaiakan tugas dan efek dari menyelesaiakan tugas bagi seseorang merupakan suatu bentuk penghargaan pada dirinyasendiri.

b. Pencapaian (achievement)

Pencapaian merupakan penghargaan yang muncul dalam diri sendiri, yang diperoleh ketika seseorang meraih suatu tujuan yang menantang.

c. Otonomi (autonomy)

Sebagian orang menginginkan pekerjaan yang memberikan hak untuk mengambil keputusan dan bekerja tanpa diawasi dengan ketat. Perasaan otonomi dapat dihasilkan dari kebebasan melakukan apa yang terbaik oleh karyawan dalam situasi tertentu.

\subsubsection{Tujuan Reward}

Menurut Gibson (dalam Erlangga, hal 169), menyatakan bahwa tujuan Reward adalah:

1. Menarik (Attract) 
Reward harus mampu menarik orang yang berkualitas untuk menjadi anggota organisasi.

2. Mempertahankan (Retain)

Reward juga bertujuan untuk mempertahankan pegawai dari incaran organisasi lain. Sistem reward yang baik dan menarik mampu meminimalkan jumlah pegawai yang keluar.

3. Memotivasi (Motivate)

Sistem reward yang baik harus mampu meningkatkan motivasi pegawai untuk mencapai prestasi yang tinggi.

\subsubsection{Dampak Pemberian Reward}

Bagi perusahaan secara umum pemberian reward kepada karyawan memiliki berbagai tujuan dan dampak yang akan dirasakan oleh karyawan tersebut seperti dikemukakan oleh Irham Fahmi (2016:65) yaitu:

1. Untuk memberikan dan menjalangkan hak dan kewajiban yang diterima oleh seorang karyawan.

2. Untuk memenuhi keinginan yang menjadi keinginan karyawan sesuai dengan kesepakatan yang ditandatangani.

3. Untuk menggambarkan wibawa perusahaan bahwa mampu membayar reward dan berbagai bentuk reward lainnya secara tepat waktu.

4. Sebagai penjelasan kepada pihak stakeholders bahwa perusahaan mampu melaksanakan kewajiban likuiditasnya secara tepat waktu. 
5. Mampu menaikan reputasi perusahaan sebagai perusahaan yang loyal dan berdedikasi tinggi dalam membangun kepedulian dan kesejahteraan karyawan.

\subsubsection{Pengertian Punishment}

Punishment adalah hukuman yang diberikan karena adanya pelanggaran terhadap aturan yang berlaku. Dalam perusahaan saksi diberikan kepada karyawan yang lalai atau melakukan kesalahan yang dapat merugikan perusahaan. Dalam hal menjaga dan meningkatkan kualitas SDM perusahan, perlu dijaga konsistensi perencanaan dengan pemberian reward serta punishment yang jelas bagi satuan kerja atau individu. Sama halnya seperti reward, pemberian punishment sebagai faktor pemicu keberhasilan perusahaan dalam meningkatkan daya saing juga memegang peranan yang penting.

Pemberian punishment terhadap satuan kerja ataun individu yang konsisten dan baik akan membuat satuan kerja atau individu tersebut semakin memacu diri untuk memperbaiki kekurangan dan kelemahan yang dimilikinya dalam menerapkan sistem ini.Menurut Irmayanti (2013), punishment adalah sebuah cara untuk mengarahkan sebuah tingkah laku agar sesuai dengan tingkah laku yang berlaku secaraumum.

Punishment adalah sebuah cara untuk mengarahkan sebuah tingkah laku agar sesuai dengan tingkah laku yang berlaku secara umum. Dalam hal ini, hukuman akan diberikan ketika sebuah tingkah laku yang tidak diharapkan ditampilkan oleh orang yang bersangkutan atau orang yang 
bersangkutan tidak memberikan respon atau tidak menampilkan sebuah tingkah laku yang diharapkan. Punishment biasanya berupa suatu ganjaran yang dapat memberikan efek jera kepada individu atau organisasi yang diberikan sanksi tersebut (Febrianti, Al Musadieq, \& Prasetya, 2014).

Punishment didefinisikan sebagai tindakan menyajikan konsekuensi yang tidak menyenangkan atau tidak diinginkan sebagai hasil dari dilakukanya perilaku tertentu (Ivancevich, Konopaske, dan Matteson 2006:226). Penjelasan lainnya seperti yang dikemukakan Mangkunegara (2013: 130) hukuman (punishment) adalah ancaman hukuman yang bertujuan untukmemperbaiki kinerja karyawan pelanggar, memelihara peraturan yangberlaku dan memberikan pelajaran kepada pelanggar

Menurut Siagian 2006 (Paper Academia, 2015:2-3) terdapat beberapa indikator punishment yaitu usaha meminimalisir kesalahan yang akan terjadi, adanya hukuman yang lebih berat bila kesalahan yang sama dilakukan, hukuman diberikan dengan adanya penjelasan, hukuman segera diberikan setelah terbukti adanya penyimpangan.

Dari beberapa pendapat para ahli tersebut, dapat disimpulkan bahwa Punishment atau sanksi merupakan ganjaran yang diberikan atas kesalahan atau kelalaian yang dilakukan oleh seseorang sesuai dengan tingkat kesalahan yang dibuat. Punishment ini dapat berupa hukuman ringan maupun berat.

\subsubsection{Indikator Punishment}

Menurut Rivai (2014:450) ada beberapa indikator Punishment, yaitu : 
1. Hukuman ringan

Hukuman ringan yaitu teguran lisan kepada karyawan yang bersangkutan, teguran tertulis dan pernyataan tidak puas secara tidak tertulis.

2. Hukuman sedang

Hukuman sedang yaitu penundaan kenaikan gaji yang sebelumnya telah direncanakan. sebagaimana karyawan lainya, penurunan gaji yang besaranya disesuai dengan peraturan perusahaan dan penundaan kenaikan pangkat atau promosi.

3. Hukuman berat

Hukuman berat yaitu dengan penurunan pangkat atau demosi. pembebasan dari jabatan, pemberhentian kerja atas permintaan karyawan yang bersangkutan dan pemutusan hubungan kerja sebagai karyawan di perusahaan.

Menurut Purwanto dalam Pahlevi (2014), indikator punishment adalah sebagai berikut:

1. Tata tertib.

2. Usaha meminimalisir kesalahan yang akan datang.

3. Paksaan/ tekanan.

4. Hukuma.n di berikan dengan adanya penjelasan.

5. Teguran.

6. Peringatan.

7. Kebijakan PHK. 
Menurut Siagian (2006), terdapat beberapa indikator punishment yaitu:

1. Usaha meminimalisir kesalahan yang akan terjadi.

Jika dalam suatu perusahaan atau organisasi karyawan harus bisa meminimalisir kesalahan yang dibuat dalam berkerja, karena jika karyawan tersebut terus-menerus melakukan kesalahan perusahaan tersebut akan memberikan punishmentnya.

2. Adanya hukuman yang lebih berat bila kesalahan yang sama dilakukan. Hukuman yang diberikan oleh atasan semata-mata akan membuat karyawan jera melakukan kesalahan, tetapi jika karyawan tersebut melakukan kesalahan yang sama maka dilakukan atasan akan memberikan hukuman yang lebih berat.

3. Hukuman diberikan dengan adanya penjelasan.

Seseorang karyawan perlu menanyakan kejelasan kepada atasanya, apa hukumannya jika karyawan tersebut melakukan kesaalahan ringan dan apa hukumnya jika karyawan melakukan kesalahan yang berat.

4. Hukuman segera diberikan setelah terbukti adanya penyimpangan.

Dengan adanya pengawasan kepada karyawan atasan bisa memantau para karyawan yang berkerja pada perusahaan tersebut, jika karyawan tersebut melakukan kesalahan dan terbukti melakukan kesalahan tersebut maka atasan langsung memberikan hukuman yang sesuai dengan kesalahan tersebut. 


\subsubsection{Mekanisme Dan Dampak Punishment}

Setiap sanksi yang diberikan atas dasar kesalahan yang dilakukan maka disana ada mekanismenya yang harus diperhatiakan. Adapun mekanisme umum bentuk pemberian punishment tersebut, seperti yang dikemukakan oleh Irham Fahmi (2016:68-69).

1. Pemberian punishment langsung berpengaruh pada finansial/ reward kepada karyawan tersebut, seperti pemotongan atau perhentikan gaji, tunjangan, bonus dan lainnya.

2. Pemberian punishment tidak langsung berpengaruh pada finansial / reward kepada karyawan tersebut, namun membawa dampak pada psikologi karyawan secara nyata.

Adapun dampak yang mungkin terjadi ketika keputusan punishment diberikan subjektif seperti yang dikemukakan oleh Irham Fahmi (2016:69) adalah sebagai berikut:

1. Wibawa dan reputasipimpinan akan turun dan tidak lagi diciptkan oleh karyawan.

2. Memungkinkan karyawan memiliki prestasi dan kompetensi bagus untuk secepatnya mengambil sikap keluar dari perusahan dan mencari perusahaan lain yang lebih nyaman.

3. Timbulnya berbagai fitnah dan informasi yang tidak betul namun diterima oleh pimpinan sebagai kebenaran dan fitnah tersebut kemudian dilakasanakan sehingga ada pihak yang dikorbangkan oleh fitnah tersebut. 
4. Memungkinkan pimpinan tersebut untuk diturunkan jabatannya dari posisi pimpinan tertinggi atas dasar keputusan yang tidak objektif tersebut.

\subsubsection{Faktor - Faktor Yang Mempengaruhi Punishment}

Menurut Mangkuprawira (2009) menjelaskan bahwa sanksi yang diterima karyawan harus sebanding dengan pelanggaran yang dilakukannya. Berikut beberapa tingkat pelanggaran karyawan dan sanksi yang diterima atas tingkat pelanggarannya yaitu:

1. Pelanggaran Tingkat I

1. Datang terlambat tanpa pemberitahuan.

2. Mengganggu kinerja kantor dalam bentuk apapun. Pulang sebelum jam yang telah ditentukan tanpa alasan yang jelas.

3. Membawa senjata tajam, minuman keras, dan merokok di tempat kerja.

2. Pelanggaran Tingkat II

a. Tidak masuk kerja selama 3 hari atau lebih tanpa ijin, baik secara tertulis maupun lisan.

b. Sering datang terlambat dan pulang lebih awal tanpa alas an jelas.

c. Menggunakan fasilitas kantor untuk keperluan pribadi.

d. Tidak mematuhi peraturan yang telah ditentukan.

3. Pelanggaran Tingkat III

1. Tidak dapat menjalankan pekerjaannya dengan baik.

2. Merusak fasilitas kantor dengan sengaja. 
3. Melecehkan pihak yang masih berhubungan dengan lingkungan kerja.

4. Mencuri asset perusahaan.

5. Membocorkan rahasia perusahaan kepada pihak lain yang bukan karyawan atau pihak terkait dengan perusahaan.

\subsubsection{Pengaruh Antar Variabel}

\subsubsection{Pengaruh Reward Terhadap Kinerja Karyawan}

Reward merupakan pengaruh siginifikan terhadap kinerja karyawan dan hal tersebut sesuai dengan pendapat yang di kemukakan oleh (Oemar(2017 : 127)) dalam Silfia Febrinti,at all (2014:7)) bahwah reward merupakan imbalan yang di berikan perusahaan kepada karyawan atau kinerja yang di berikan. Maksudnya adalah reward diberikan perushaan kepada karyawan sebagai bentuk apresisi perusahaan kepada karyawan kinerja yang diberikan tanggung jawab dalam berkerja. Secara umum pemberian reward pada karyawan untuk meningkatkan kinerja karyawan sehingg tujuan perusahaan dapat tercapai, selain itu dengan adanya reward merasa kontribusinya yang diberikan dihargai sehingga memacau kinerja karyawan semakin meningkat. Dapat dikatakan bahwa kinerja karyawan dipengaruhi oleh reward yang baik yang berasal dari gaji, tunjangn, bonus, penghargaan interpersonal berupa pujian, promosi dan pencapaian berupa rasa puas dan bangga dari perusahaan. 


\subsubsection{Pengaruh Punishment Terhadap Kinerja Karyawan}

Punishment memberikan yang segnifikan terhadap kinerja karyawan sesuai dengan pendapat yang di kemukakan oleh (Mangkunegara (2013 : 130) dalam Silfin Febrianti at all ( 2014 )). Punishment adalah ancaman atau hukuman yang bertujuan untu memperbaiki karyawan yang melangar. Pelajaran tersebut nantinya dapat merubah sikap karywan yang kurang baik menjadi lebih baik, sehingga berdampak pada kinerja yang baik dan profesional. Secara umum pemberian punishment pada karyawan bertujuan untuk meningkatkan kinerja perusahaan yang dapat tercapai, selain itu dengan adanya punishment pada karyawan akan merasa lebih bertanggung jawab dalam berkerja. Hal ini dapat dikatakan bahwa kinerja karyawan dipengaruhi oleh adanya punishment berupa hukuman ringan, hukuman sedang dan hukuman berat.

\subsubsection{Pengaruh Reward Dan Punishment Terhadap Kinerja Karyawan}

Berdasarkan hasil penelitian terdahulu Ruslan Mas`Ud all (2017:6), Amir (2019:2), Rohimat Nurhasan (2016:35-40) menyatakan terdapat pengaruh secara bersama-sama antara reward dan punishment terhadap kinerja karyawan. Pengujian secara statistik membuktikan bahwa punishment berpengaruh positif terhadap kinerja karyawan. Artinya bahwa reward dan punishment mempegaruhi kinerja karyawan. 


\subsection{Hasil Penelitian Yang Relevan}

Ada beberapa penelitian terdahulu yang digunakan oleh penulis sebagai bahan dan materi rujukan yang mendukung penelitian ini, beberapa penelitian tersebut telah dirangkum penulis dan akan disajikan dalam tabel berikut :

Tabel 2.1

\begin{tabular}{|c|c|c|c|}
\hline No & Peneliti & Judul penelitian & Hasil penelitian` \\
\hline 1. & $\begin{array}{l}\text { Amin Karami,Hossein } \\
\text { Rezaei Dolatabadi, } \\
\text { and Dr. Saeed } \\
\text { Rajaeepour/Islamic } \\
\text { Azad University, } \\
\text { Najafabad University } \\
\text { of Isfahan/2013 }\end{array}$ & $\begin{array}{l}\text { Analyzing the } \\
\text { Effectiveness of } \\
\text { Reward } \\
\text { Management } \\
\text { System } \\
\text { Employee } \\
\text { Performance } \\
\text { through the } \\
\text { Mediating Role of } \\
\text { Employee }\end{array}$ & $\begin{array}{l}\text { Sistem manajemen } \\
\text { Penghargaan } \\
\text { memiliki pengaruh } \\
\text { positif dan signifikan } \\
\text { Terhadap motivasi } \\
\text { kerja karyawan. } \\
\text { Motivasi karyawan } \\
\text { tidak berpengaruh } \\
\text { positif dan signifikan } \\
\text { terhadap kinerja } \\
\text { karyawan. Sistem } \\
\text { manajemen } \\
\text { penghargaan } \\
\text { memiliki pengaruh } \\
\text { positif dan signifikan } \\
\text { terhadap kinerja } \\
\text { karyawan (dengan } \\
\text { adanya motivasi } \\
\text { sebagai variabel } \\
\text { perantara). }\end{array}$ \\
\hline 2. & $\begin{array}{l}\text { Silfia Febrianti, } \\
\text { Mochammad Al } \\
\text { Musadieq, Arik } \\
\text { Prasetya/Fakultas } \\
\text { Ilmu Administrasi } \\
\text { Universitas Brawijaya } \\
\text { Malang/2014 }\end{array}$ & $\begin{array}{lr}\text { Pengaruh reward } \\
\text { dan punishment } \\
\text { terhadap motivasi } \\
\text { kerja } & \text { serta } \\
\text { dampaknya } \\
\text { terhadap } \\
\text { (studi } r \text { inerja } \\
\text { karyawan } r \text { Pada } \\
\text { Panin bank tbk. } \\
\text { Area } \\
\text { Jombang }\end{array}$ & 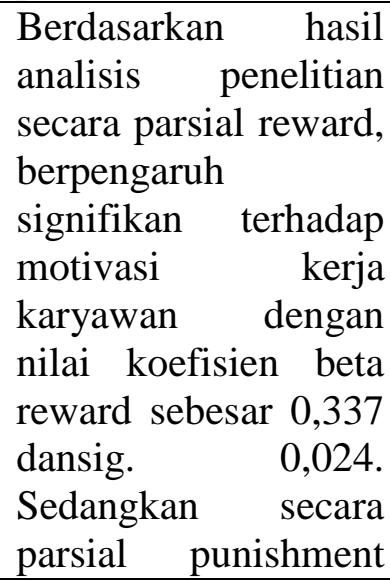 \\
\hline
\end{tabular}




\begin{tabular}{|c|c|c|c|}
\hline & & & $\begin{array}{lr}\text { berpengaruh } & \text { tidak } \\
\text { signifikan terhadap } \\
\text { motivasi kerja } \\
\text { karyawan dengan } \\
\text { nilai koefisien beta } \\
\text { punishment sebesar } \\
0,147 \text { dansig. } 0,313 . \\
\text { Secara simultan } \\
\text { reward, punishment, } \\
\text { dan motivasi kerja } \\
\text { karyawan } \\
\text { berpengaruh } \\
\text { signifikan terhadap } \\
\text { kinerja karyawan, hal } \\
\text { ini ditunjukkan } \\
\text { melalui koefisien } \\
\text { beta reward sebesar } \\
0,227 \text { dansig. } 0,042 . \\
\text { Koefisien beta } \\
\text { punishment } \\
\text { mendapatkan hasil } \\
\text { sebesar } 0,210 \text { dan sig. } \\
0,047 \text {, serta koefisien } \\
\text { beta motivasi kerja } \\
\text { karyawan sebesar } \\
0,561 \text { dan nilai sig. } \\
0,000 \text {. }\end{array}$ \\
\hline 3. & $\begin{array}{l}\text { Kevin Tangkuman, } \\
\text { Bernhard Tewal, Irvan } \\
\text { Trang/Fakultas } \\
\text { Ekonomi dan Bisnis, } \\
\text { Jurusan Manajemen } \\
\text { Universitas } \\
\text { Ratulangi Sam } \\
2015\end{array}$ & $\begin{array}{l}\text { Penilaian kinerja, } \\
\text { reward,dan } \\
\text { punishment } \\
\text { terhadap kinerja } \\
\text { karyawan pada } \\
\text { PT. Pertamina } \\
\text { (persero) cabang } \\
\text { pemasaran } \\
\text { Suluttenggo }\end{array}$ & $\begin{array}{lr}\text { Hasil } & \text { analisis } \\
\text { penelitian } & \text { secara } \\
\text { simultan penilaian } \\
\text { kinerja, reward dan } \\
\text { punishment, } \\
\text { berpengaruh } \\
\text { signifikan terhadap } \\
\text { kinerja karyawan. } \\
\text { Secara rarsial } \\
\text { penilaian kinerja, } \\
\text { reward } \\
\text { punishment secara } \\
\text { parsial, berpengaruh } \\
\text { signifikan terhadap } \\
\text { kinerja karyawan }\end{array}$ \\
\hline 4. & $\begin{array}{l}\text { Rendra } \\
\text { Suryadilaga, } \\
\text { Mochammad } \\
\text { Musadieq, Gunawan } \\
\end{array}$ & 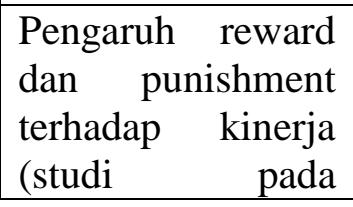 & $\begin{array}{lr}\text { Reward } & \text { dan } \\
\text { Punishment } & \text { secara } \\
\text { simultan berpengaruh } \\
\text { signifikan terhadap }\end{array}$ \\
\hline
\end{tabular}




\begin{tabular}{|c|c|c|c|}
\hline & $\begin{array}{l}\text { Eko Nurtjahjono } \\
\text { /Universitas } \\
\text { Brawijaya } \\
\text { Malang/2016 }\end{array}$ & $\begin{array}{lr}\text { karyawan } & \text { PT. } \\
\text { Telkom Indonesia } \\
\text { Witel r Jatim } \\
\text { Selatan Malang) }\end{array}$ & $\begin{array}{l}\text { Kinerja Karyawan di } \\
\text { PT Telkom Indonesia } \\
\text { Witel Jatim Selatan } \\
\text { Malang sebesar } 0,574 \\
\text { atau } 57,4 \% \text {. }\end{array}$ \\
\hline 5. & $\begin{array}{l}\text { Suparmi, } \\
\text { Septiwan / Fakultas } \\
\text { Ekonomi Dan Bisnis, } \\
\text { Universits } 17 \text { Agustus } \\
\text { 1945 Semarang }\end{array}$ & $\begin{array}{l}\text { Reward dan } \\
\text { punishment } \\
\text { sebagai pemicu } \\
\text { kinerja karyawan } \\
\text { pada PT Dunia } \\
\text { Setia Sandang Asli } \\
\text { Iv Ungaran }\end{array}$ & 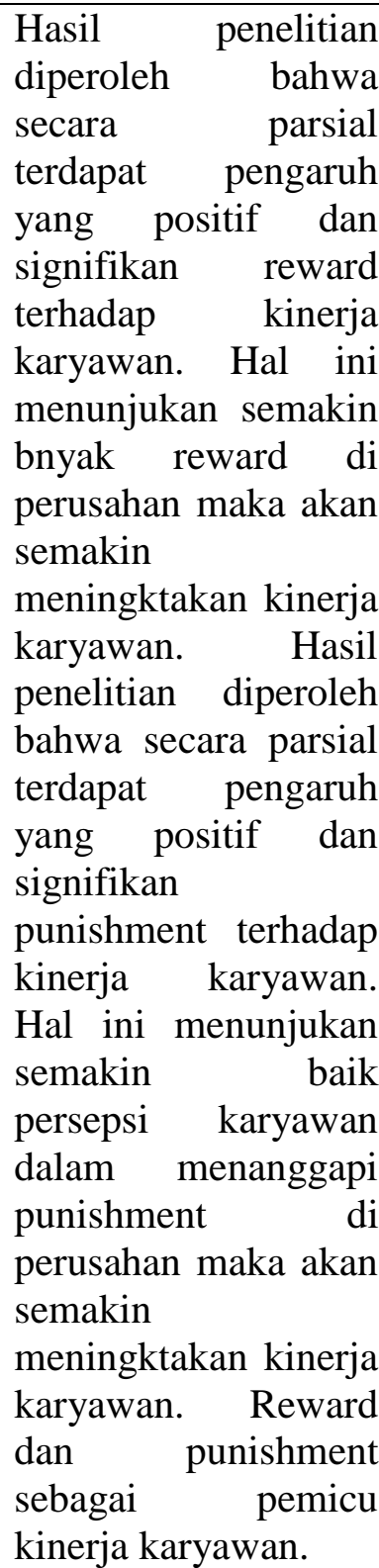 \\
\hline 6. & \begin{tabular}{lr}
\multicolumn{2}{l}{ Rohimat Nurhasan } \\
Daniyati & Solehah/ \\
Fakultas & Ekonomi \\
Universitas & Garut/ \\
2016 &
\end{tabular} & $\begin{array}{l}\text { Pengaruh } \\
\text { penerapan reward } \\
\text { and punishment } \\
\text { terhadap kinerja } \\
\text { pegawai dan } \\
\text { dampaknya } \\
\text { terhadap kinerja } \\
\text { Pdam Tirta Intan }\end{array}$ & $\begin{array}{l}\text { Hasil dari penelitin } \\
\text { ini diketahui bahwa } \\
\text { variabel reward and } \\
\text { punishment } \\
\text { berpengaruh } \\
\text { signifikan terhadap } \\
\text { kinerja pegawai, } \\
\text { variabel kinerja }\end{array}$ \\
\hline
\end{tabular}




\begin{tabular}{|c|c|c|c|}
\hline & & Garut & $\begin{array}{l}\text { pegawai berpengaruh } \\
\text { signifikan terhadap } \\
\text { kinerja perushaan, } \\
\text { variabel reward and } \\
\text { punishment } \\
\text { berpengaruh } \\
\text { signifikan terhadap } \\
\text { kinerja perusahaan. }\end{array}$ \\
\hline 7. & $\begin{array}{l}\text { Ruslan Mas'ud, LCA, } \\
\text { Robin Jonathan, } \\
\text { Elfreda Aplonia } \\
\text { Lau/fakultas ekonomi } \\
\text { universitas } 17 \text { agustus } \\
\text { 1945 samarinda/ } 2017\end{array}$ & $\begin{array}{l}\text { Pengaruh reward } \\
\text { dan punishment } \\
\text { terhadap kinerja } \\
\text { pegawi di dinas } \\
\text { pendidikan dan } \\
\text { kebudayakan } \\
\text { kabupaten kutai } \\
\text { timur }\end{array}$ & $\begin{array}{lr}\text { Hasil penelitian } \\
\text { menunjukkan bahwa } \\
\text { reward berpengaruh } \\
\text { positif dan segnifikan } \\
\text { terhadap kinerja, } \\
\text { punishment } \\
\text { berpengaruh positif } \\
\text { dan segnifikan } \\
\text { terhadap kinerja, } \\
\text { reward dan } \\
\text { punishment } \\
\text { berpengaruh positif } \\
\text { dan segnifikan } \\
\text { terhadap kinerja }\end{array}$ \\
\hline 8. & 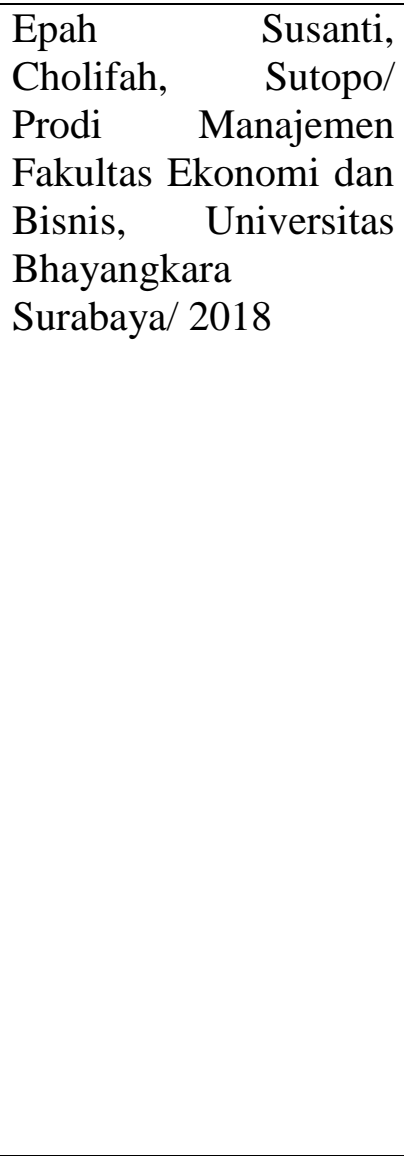 & $\begin{array}{l}\text { Pengaruh Reward } \\
\text { dan Punishment } \\
\text { terhadap kinerja } \\
\text { Karyawan Pada } \\
\text { PT. Ciomas } \\
\text { Adisatwa } \\
\text { di Sidoarjo }\end{array}$ & 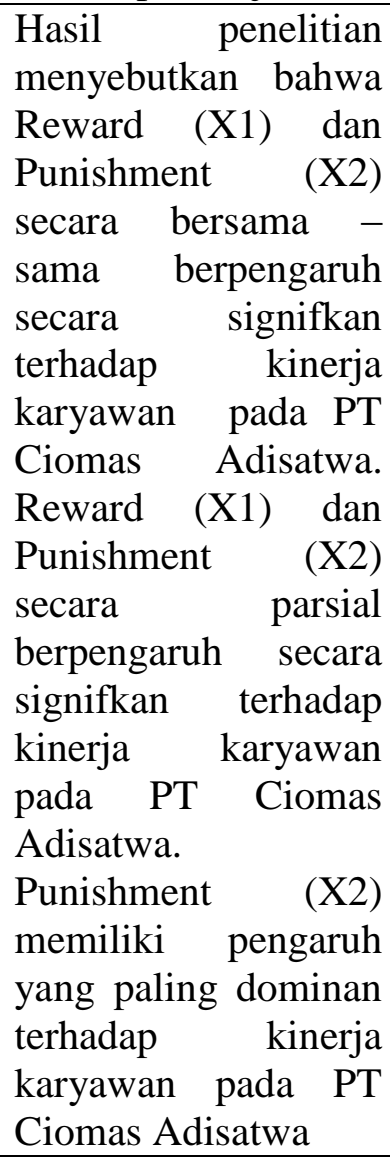 \\
\hline
\end{tabular}




\begin{tabular}{|c|c|c|c|}
\hline 9. & $\begin{array}{l}\text { Hidayatulloh, } \\
\text { Muchammad Riyan/ } \\
\text { Fakultas Ekonomi } \\
\text { Program } \\
\text { Manajemen, } \\
\text { Universitas } \\
\text { Majapahit / } 2018\end{array}$ & $\begin{array}{l}\text { Pengaruh } \\
\text { pemberian Reward } \\
\text { dan Punishment } \\
\text { terhadap } \\
\text { kinerja karyawan } \\
\text { Pada PT. Pln } \\
\text { (Persero) } \\
\text { Mojokerto }\end{array}$ & $\begin{array}{l}\text { Hasil penelitian } \\
\text { menyebutkan bahwa } \\
\text { Reward dan } \\
\text { punishment } \\
\text { berpengaruh secara } \\
\text { Simultan terhadap } \\
\text { kinerja Karyawan PT. } \\
\text { PLN (Persero) Area } \\
\text { Mojokerto. Reward } \\
\text { berpengaruh secara } \\
\text { Parsial terhadap } \\
\text { kinerja Karyawan PT. } \\
\text { PLN (Persero) Area } \\
\text { Mojokerto. Dan } \\
\text { sedangkan tidak } \\
\text { punishment } \\
\text { berpengaruh secara } \\
\text { Parsial terhadap } \\
\text { kinerja Karyawan PT. } \\
\text { PLN (Persero) Area } \\
\text { Mojokerto. }\end{array}$ \\
\hline 10. & $\begin{array}{l}\text { Adhitomo Wirawan, } \\
\text { Ismi Nur Afani/ Prodi } \\
\text { Administrasi Bisnis } \\
\text { Terapan Politeknik } \\
\text { Negeri Batam/ } 2018\end{array}$ & 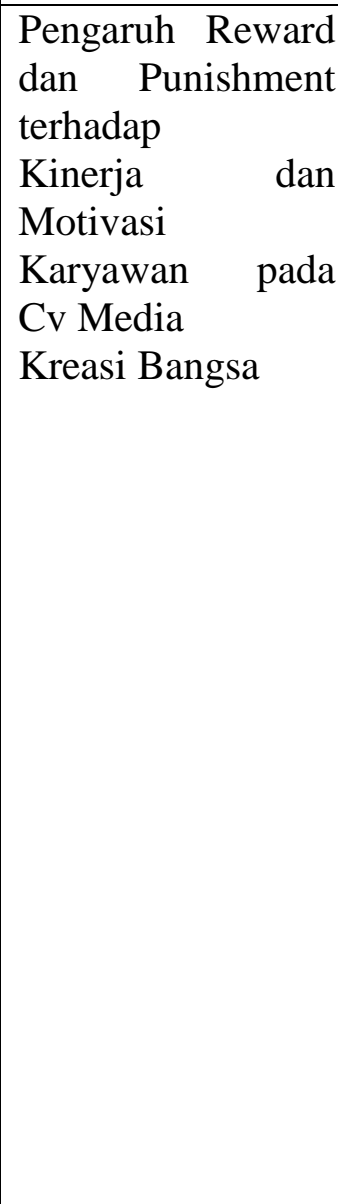 & $\begin{array}{l}\text { Hasil penelitian ini } \\
\text { adalah variabel } \\
\text { reward berpengaruh } \\
\text { positif terhadap } \\
\text { kinerja hal ini dilihat } \\
\text { dari t hitung }(2,363) \\
\text { lebih besar dari } t \\
\text { tabel (1,65) dengan } \\
\text { tingkat signifikan } \\
(0,020 \quad<\quad 0,05) \text {. } \\
\text { Variabel reward } \\
\text { berpengaruh positif } \\
\text { terhadap motivasi hal } \\
\text { ini dilihat dari } t \\
\text { hitung (4,289) lebih } \\
\text { besar dari t tabel } \\
(1,65) \text { dengan tingkat } \\
\text { signifikan (0,000 } \\
0,05) \text { Terdapat } \\
\text { pengaruh secara } \\
\text { simultan antara } \\
\text { variabel reward dan } \\
\text { punishment terhadap } \\
\text { kinerja hal ini dilihat } \\
\text { dari F hitung }\end{array}$ \\
\hline
\end{tabular}




\begin{tabular}{|c|c|c|c|}
\hline & & & 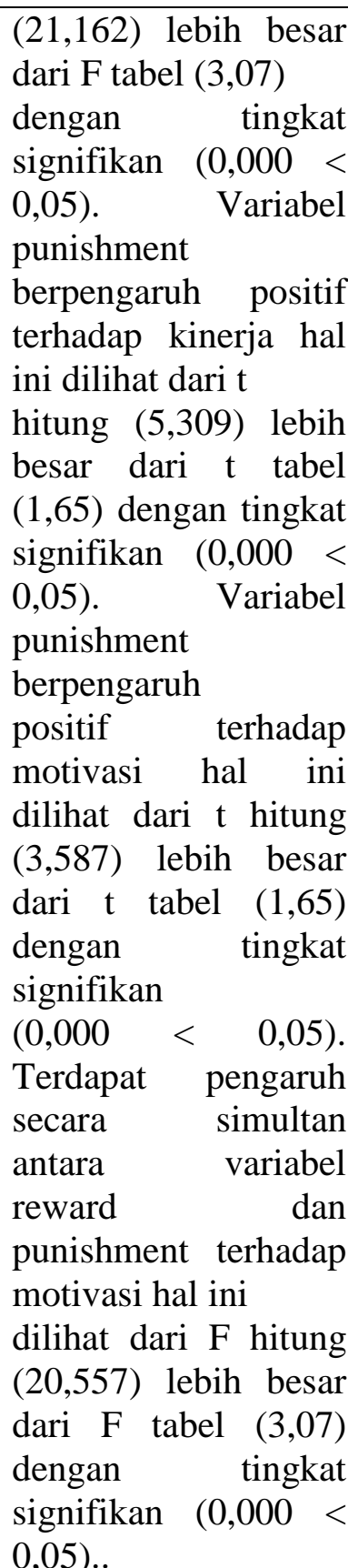 \\
\hline 11. & $\begin{array}{l}\text { Amri/Fakultas } \\
\text { Ekonomi Universitas } \\
\text { Andi Djemma/ } 2019\end{array}$ & $\begin{array}{l}\text { Pengaruh Reward } \\
\text { Dan Punishment } \\
\text { Terhadap Kinerja } \\
\text { Karyawan } \\
\text { Pada Ksp Balota } \\
\text { Kota Palopo }\end{array}$ & $\begin{array}{lr}\text { Hasil penelitian } \\
\text { menunjukkan } & \text { bahwa } \\
\text { Reward } & \text { dan } \\
\text { Punishment } & \text { secara } \\
\text { bersama-sama } & \\
\text { berpengaruh } & \\
\text { terhadap } & \text { kinerja } \\
\text { karyawan pada } & \text { KSP } \\
\text { BALOTA } & \text { Kota } \\
\text { Palopo. } & \text { Secara }\end{array}$ \\
\hline
\end{tabular}




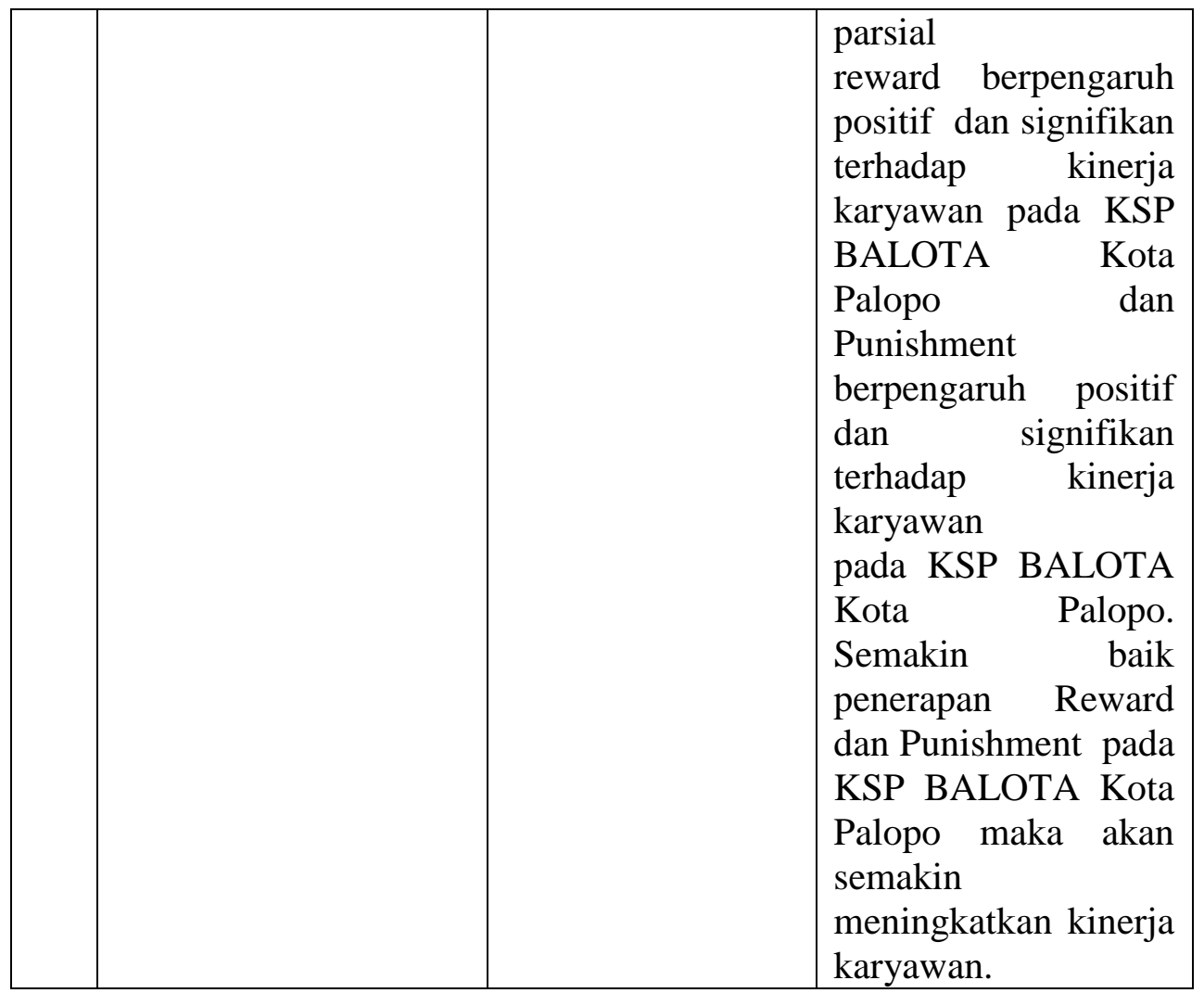

\subsection{Kerangka Konseptual}

Berikut ini diuraikan suatu rencana penelitian yang digambarkan dari kerangka/analisis "Pengaruh pemberian reward dan punishment terhadap kinerja karyawan pada PT. Sandabi Indah Lestari Bengkulu Utara”. 
Gambar 2.1

Kerangka Konseptual

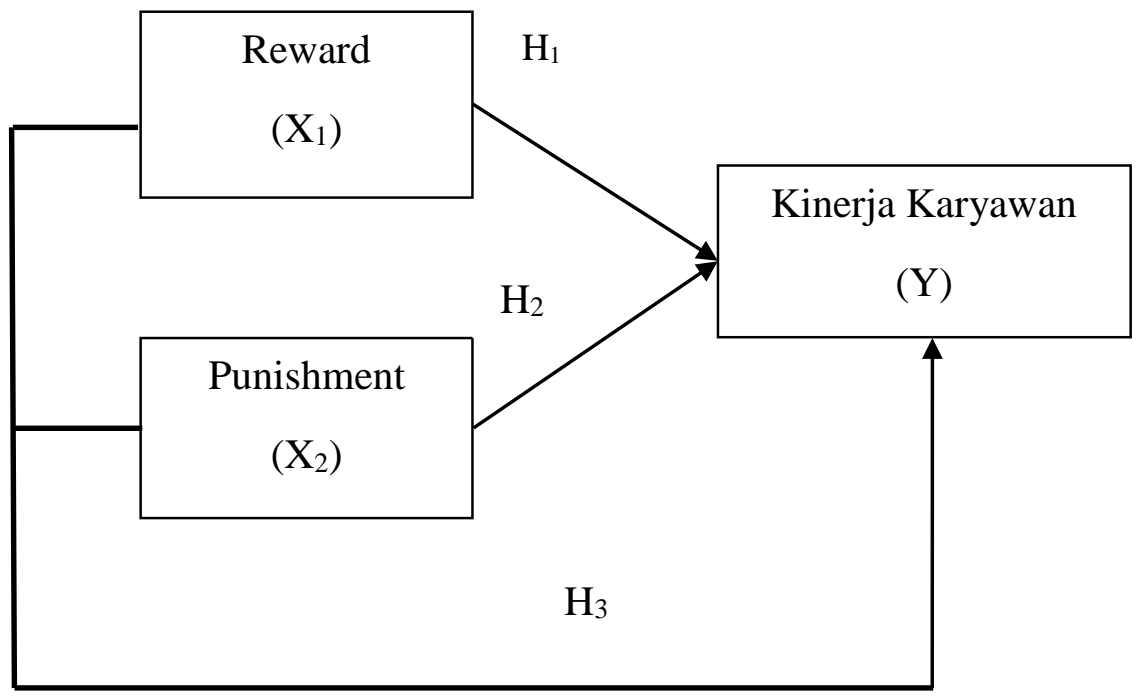

Keterangan :

$\mathrm{X}_{1} \quad$ : Variabel pengaruh (Reward)

$\mathrm{X}_{2} \quad$ : Variabel Pengaruh (Punishment)

Y : Variabel Terpengaruh (Kinerja)

$\longrightarrow \quad$ : Menunjukkan pengaruh langsung dari pengaturan reward dan punishment terhadap kinerja karyawan.

\subsection{Definisi Operasional}

Variabel penelitian pada dasarnya adalah segala sesuatu yang berbentuk apa saja yang ditetapkan oleh peneliti untuk dipelajari sehingga diperoleh informasi tentang hal tersebut, kemudian ditarik kesimpulannya (Sugiyono, 2010). Variabel penelitian merupakan elemen penting dalam suatu penelitian yang harus dianalisa. 
Tabel 2.2

Definisi Operasional Penelitian

\begin{tabular}{|c|c|c|c|c|}
\hline Variabel & $\begin{array}{l}\text { Definisi } \\
\text { Operasional }\end{array}$ & Indikator & Alat ukur & $\begin{array}{l}\text { Skala } \\
\text { Ukur }\end{array}$ \\
\hline Kinerja & $\begin{array}{lr}\text { Bahwa } & \text { kinerja } \\
\text { dapat diartikan } \\
\text { sebagai suatu hasil } \\
\text { kerja ra } \\
\text { pencapaian prestasi } \\
\text { kerja seorang } \\
\text { pegawai dalam } \\
\text { melaksanakan } \\
\text { tugasnya sesuai } \\
\text { dengan wewenang } \\
\text { dan tanggungjawab } \\
\text { masing-masing } \\
\text { yang berkaitan } \\
\text { dengan tujuan } \\
\text { strategis organisasi, } \\
\text { kepuasan } \\
\text { konsumen } \\
\text { memberikan dan } \\
\text { kontribusi } \\
\text { ekonomi. }\end{array}$ & $\begin{array}{l}\text { 1. Kuantitas } \\
\text { 2. kualitas } \\
\text { 3. produktivi } \\
\text { tas } \\
\text { 4. ketepatan } \\
\text { waktu } \\
\text { 5. pengawasa } \\
\text { n biaya } \\
\text { (Wibowo } \\
\text { 2016:173) }\end{array}$ & Kuesioner & Ordinal \\
\hline Reward & $\begin{array}{lr}\text { Merupakan } & \text { salah } \\
\text { satu cara atau } \\
\text { metode untuk } \\
\text { meningkatkan } \\
\text { motivasi seseorang } \\
\text { atau organisasi } \\
\text { supaya bisa terus } \\
\text { melakukan hal } \\
\text { yang baik dan } \\
\text { berprestasi. } \\
\text { Sehingga nantinya } \\
\text { akan mendapatkan } \\
\text { balas jasa berupa } \\
\text { penghargaan, baik } \\
\text { berupa materil } \\
\text { maupun non } \\
\text { materil. na non }\end{array}$ & $\begin{array}{l}\text { 1. Gaji } \\
\text { 2. Upah } \\
\text { 3. Insetif } \\
\text { 4. Tujangan } \\
\text { 5. Pengharaa } \\
\text { n } \\
\text { interperso } \\
\text { nal } \\
\text { 6. Promosi } \\
\text { Kadarisman } \\
\text { (2012: } 122) \text {, }\end{array}$ & Kuesioner & Ordinal \\
\hline Punishment & $\begin{array}{lr}\text { Merupakan } & \\
\text { ganjaran } & \text { yang } \\
\text { diberikan } & \text { atas }\end{array}$ & $\begin{array}{l}\text { 1. Hukuman } \\
\text { ringan } \\
\text { 2. Hukuman }\end{array}$ & Kuesioner & Ordinal \\
\hline
\end{tabular}




\begin{tabular}{|l|lr|l|l|}
\hline & $\begin{array}{lr}\text { kesalahan } r a u \\
\text { kelalaian }\end{array}$ yang & 3. Hukuman & & \\
dilakukan & oleh & berat & \\
seseorang & sesuai & Rivai & \\
dengan & tingkat & $(2014: 450)$ & \\
kesalahan $\quad$ yang & & \\
dibuat. Punishment & & \\
ini dapat berupa & & \\
hukuman ringan & & \\
maupun berat. & & \\
\hline
\end{tabular}

\subsection{Hipotesis}

Berdasarkan uraian kerangka pemikiran dan hasil kajian empiris diatas maka penelitian mengajukan beberapa hipotesis dalam penelitian ini sebagai berikut:

$\mathrm{H}_{1}$ : Diduga reward berpengaruh secara signifikan terhadap kinerja karyawan pada PT. Sandabi Indah Lestari Bengkulu Utara.

$\mathrm{H}_{2}$ : Diduga Punishment berpengaruh secara signifikan terhadap kinerja karyawan pada PT. Sandabi Indah Lestari Bengkulu Utara.

$\mathrm{H}_{3}$ : Diduga Reward dan Punishement berpengaruh secara silmutan terhadap Kinerja Karyawan pada PT. Sandabi Indah Lestari Bengkulu Utara. 


\section{BAB III \\ METODE PENELITIAN}

\subsection{Tempat Dan Waktu Penelitian}

Penelitian ini akan dilaksanakan di Desa Lubuk Banyau Kecamatan Padang Jaya Bengkulu Utara. Dan waktu penelitian akan dilaksanakan pada Bulan Februari 2020 sampai dengan selesai.

\subsection{Jenis Penelitian}

Penelitian ini termasuk penelitian kuantitatif. Menurut Sugiyono, (2017) penelitain kuantitatif adalah suatu penelitian yang berpola investigasi dimana data-data dan pertanyaan diperoleh dari hasil interaksi langsung antara peneliti, objek yang diteliti dan orang-orang yang ada ditempat penelitian. Penelitian kuantitatif bersifat deskripsi dan cenderung menggunakan analisis dengan pendekatan induktif. Pada penelitian ini menganalisi pengaruh reward dan punishment terhadap kinerja karyawan pada PT. Sandabi Indah Lestari Bengkulu Utara

\subsection{Populasi dan Sampel}

Populasi merupakan wilayah atau tempat yang menjadi sumber penelitian. Hal tersebut di perkuat oleh pendapat Sugiyono (2017:80), menyatakan bahwa populasi adalah wilayah generalisasi yang terdiri atas objek atau subjek yang mempunyai kualitas dan karakteristik tertentu yang ditetapkan oleh peneliti untuk dipelajari dan kemudian ditarik 
kesimpulannya. Dalam penelitian ini yang menjadi populasi pada PT. Sandabi Indah Lestari yang berjumlah 125 orang Karyawan.

Sampel adalah bagian dari jumlah dan karakteristik yang dimiliki oleh populasi menurut Sugiyono (2017:137). Pengukuran sampel merupakan suatu langkah untuk menentukan besarnya sampel yang diambil untuk melaksanakan penelitian. Dalam menentukan jumlah sampel ini peneliti menggunakan rumus Slovin yaitu sebuah rumus atau formula untuk menghitung jumlah sampel minimal apabila sebuah populasi diketahui jumlahnya yaitu sebagai berikut :

$$
n=\frac{N}{1+N(e)^{2}}
$$

Keterangan :

$\mathrm{n}=$ ukuran sampel

$\mathrm{N}=$ ukuran populasi

$\mathrm{e}=$ tingkat kesalahan sampel (sampling error)

Penelitian ini menggunakan tingkat keandalan 90\% karena menggunakan tingkat kelonggaran ketidaktelitian sebesar 5\%. Menurut Sugiyono (2008 : 138) pembulatan ke atas dilakukan karena berdasarkan tabel ukuran sampel dan batas kesalahan untuk tingkat kelonggaran penelitian 5\%. Apabila dilakukan perhitungan menggunakan rumus, maka jumlah minimum yang di peroleh adalah:

$$
n=\frac{N}{1+\mathrm{N}(\mathrm{e})^{2}}=\frac{125}{1+125 \cdot(0,05)^{2}}=95,2380
$$


Sampel yang akan diambil dari populasi menggunakan convenience sampling, yaitu istilah umum yang mencakup variasi luasnya prosedur pemilihan responden. Convenience sampling merupakan pengumpulan informasi dari anggota populasi yang dengan senang hati bersedia memberikannya. Pengambilan 96 sampel yaitu dengan memberikan dan menjelaskan mengenai kuesioner pada karyawan.

\subsection{Teknik Pengumpulan Data}

Teknik pengumpulan data yang dilakukan dalam penelitian ini adalah:

1. Observasi

Menurut Sugiyono (2015: 204) observasi merupakan kegiatan pemuatan penelitian terhadap suatu objek. Data-data yang diperoleh dalam observasi itu dicatat dalam suatu catatan observasi. Kegiatan pencatatan dalam hal ini adalah merupakan bagian daripada kegiatan pengamatan.

2. Wawancara

Menurut Sugiyono (2013:231), wawancara merupakan pertemuan dua orang untuk bertukar informasi dan ide melalui tanya jawab, sehingga dapat dikontruksikan makna dalam suatu topik tertentu. Wawancara digunakan sebagai teknik pengambilan atau pengumpulan data apabila peneliti akan melaksanakan studi pendahuluan untuk menemukan permasalahan yang harus diteliti, dan juga apabila peneliti harus mengetahui hal-hal dari responden yang lebih mendalam dan jumlah respondennya sedikit. 
3. Kuesioner

Yaitu pengumpulan data yang menggunakan daftar pertanyaan kepada responden untuk diisi, kemudian jawaban yang diisi oleh responden tersebut diberi skor dengan menggunakan skala ordinal. Skala ordinal menurut Sugiyono (2010:98) adalah skala pengukuran yang tidak hanya menyatakan kategori, tetapi juga menyatakan peringkat construct yang diukur. untuk setiap pilihan jawaban diberi skor, maka responden harus menggambarkan, mendukung pernyataan. Berikut tabel skala ordinal yang digunakan.

Tabel 3.1

Skala Ordinal

\begin{tabular}{|c|c|c|}
\hline No & Peryataan & Skor \\
\hline 1. & Sangat Setuju (SS) & 5 \\
\hline 2. & Setuju (S) & 4 \\
\hline 3. & Netral (N) & 3 \\
\hline 4. & Tidak Setuju (TS) & 2 \\
\hline 5. & Sangat Tidak Setuju (STS) & 1 \\
\hline
\end{tabular}

Tabel 3.2

Kisi-kisi kuesioner

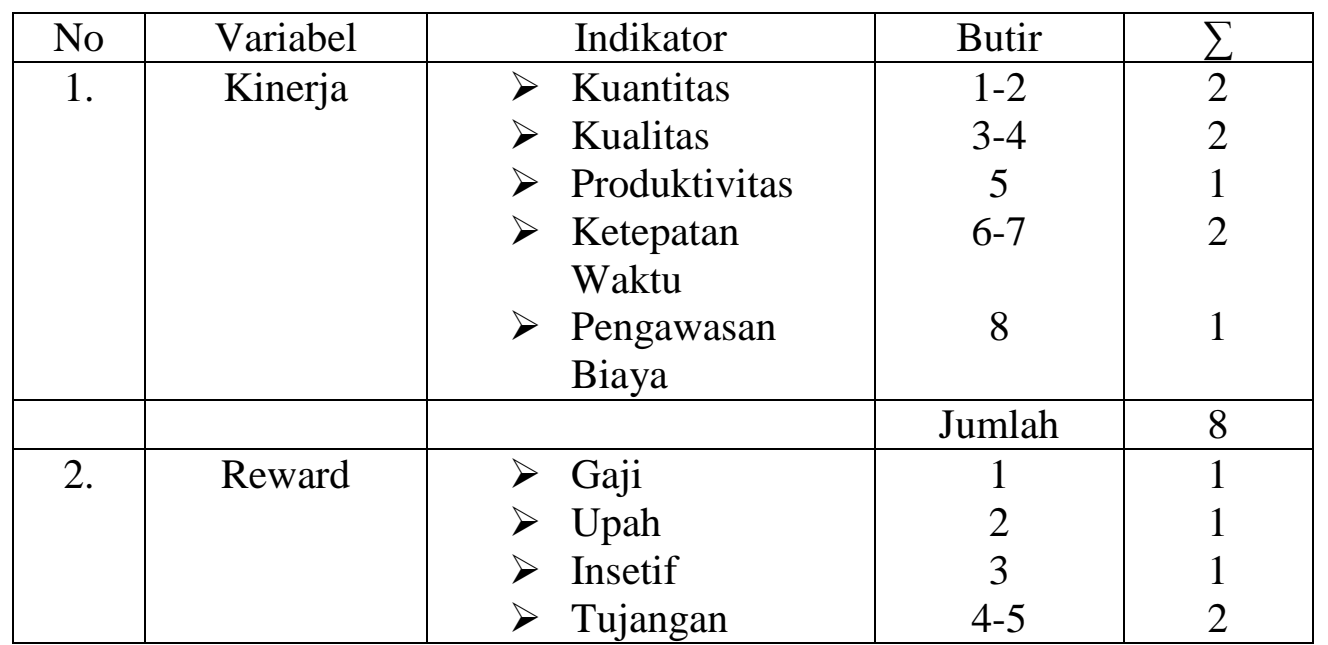




\begin{tabular}{|c|c|c|c|c|}
\hline & & $>$ & 6 & 1 \\
& & $>$ & Pengharaan \\
interpersonal & Promosi & $7-8$ & 2 \\
\hline & & & Jumlah & 8 \\
\hline 3. & Punishment & $>\begin{array}{l}\text { Hukuman } \\
\text { Ringan }\end{array}$ & $1-2$ & 2 \\
& $>\begin{array}{l}\text { Hukuman } \\
\text { Sedang }\end{array}$ & $3-4$ & 2 \\
& $>$ & Hukuman Berat & $5-6$ & 2 \\
\hline & & & Jumlah & 6 \\
\hline
\end{tabular}

\subsection{Uji Instrumen Penelitian}

Uji instrumen digunakan untuk menguji kuesioner yang telah di buat, dalam penelitian ini uji instrumen yang digunakan ada dua, yaitu uji validitas instrumen dan uji reliabilitas instrumen. Dengan menggunakan instrumen yang valid dan reliabel dalam pengumpulan data maka diharapkan hasil penelitian akan menjadi valid dan reliabel

\subsubsection{Uji Validitas Instrumen}

Pengujian ini dilakukan untuk mengetahui apakah alat ukur yang digunakan mengukur apa yang perlu diukur. Suatu alat ukur yang validitasnya tinggi akan mempunyai tingkat kesalahan kecil, sehingga data yang terkumpul merupakan data yang memadai. Validitas menunjukan sejauh mana suatu alat pengukur itu mengukur apa yang ingin diukur.

Uji validitas dalam penelitian ini digunakan analisis item, yaitu mengkorelasikan skor tiap butir dengan skor total yang merupakan jumlah dari tiap skor butir. Jika ada item yang tidak memenuhi syarat, maka item tersebut tidak akan diteliti lebih lanjut. Syarat tersebut menurut Sugiyono 
(2010:178) yang harus dipenuhi yaitu harus memiliki kriteria sebagai berikut:

a. Jika koefisien korelasi $r>0,30$ maka item tersebut dinyatakan valid,

b. Jika koefisien korelasi $\mathrm{r}<0,30$ maka item tersebut dinyatakan tidak valid.

Untuk menghitung korelasi pada uji validitas menggunakan korelasi Pearson Product Moment yang dirumuskan sebagai berikut:

$$
\mathrm{r}=\frac{N\left(\sum X Y\right)-\left(\sum X\right)\left(\sum Y\right)}{\sqrt{\left.\left[n \sum X^{2}-\left(\sum X\right)^{2}\right]\left[n \sum Y\right)^{2}\right]}}
$$

Keterangan:

$$
\begin{array}{lll}
\mathrm{r} & = & \text { Koefisien indeks korelasi product moment } \\
\mathrm{X} & = & \text { Variabel independen (variabel bebas) } \\
\mathrm{Y} & = & \text { Variabel dependen (variabel terkait) } \\
\mathrm{n} & = & \text { Jumlah responden } \\
\sum \mathrm{x}, \mathrm{y} & = & \text { Jumlah perkalian variabel bebas dan variabel terkait }
\end{array}
$$

\subsubsection{Uji Reliabilitas Instrumen}

Sebuah alat ukur atau pertanyaan dalam angket dikategorikan reliabel (andal), jika alat ukur yang digunakan dapat mengukur secara konsisten atau stabil meskipun pertanyaan tersebut diajukan dalam waktu yang berbeda (Sugiyono, 2013). Uji reliabilitas dilakukan terhadap butir pertanyaan atau pernyataan yang sudah valid. Pengujian ini digunakan untuk mengetahui seberapa jauh hasil pengukuran tetap konsisten apabila dilakukan pengukuran dua kali atau lebih terhadap gejala yang sama 
dengan menggunakan alat pengukur yang sama.melihat reliabilitas masing-masing instrumen yang digunakan, penulis menggunakan koefisien cronbach alpha $(\alpha)$ dengan menggunakan fasilitas Statistical Product and Service Solution (SPSS) versi 16 untuk jenis pengukuran interval. Suatu instrumen dikatakan reliabel jika nilai cronbach alpha lebih besar dari batasan yang ditentukan yakni 0,60 atau nilai korelasi hasil perhitungan lebih besar dari pada nilai dalam tabel dan dapat digunakan untuk penelitian, yang dirumuskan:

$$
\alpha=\frac{k}{k-\mid \mathbf{1}}\left(\mathbf{1}-\frac{\sum \mathrm{S}_{\mathrm{i}}}{\mathrm{St}}\right)
$$

keterangan :

$\alpha \quad=$ Koefisien reliabilitas

$\mathrm{k} \quad=$ Jumlah item pertanyaan yang diuji

$\sum \mathrm{S}_{\mathrm{i}} \quad=$ Jumlah variasi sekor tiap itan

$\mathrm{S}_{\mathrm{t}} \quad=$ Varians total

\subsection{Uji Asumsi Klasik}

Untuk menguji kelayakan model regresi yang digunakan, maka harus terlebih dahulu memenuhi uji asumsi klasik. Uji asumsi klasik dalam penelitian ini terdiri dari uji normalitas, uji multikolineritas, dan uji heteroskedastisitas.

\subsubsection{Uji Normalitas}

Uji normalitas bertujuan untuk menguji apakah dalam model regresi, variabel pengganggu atau residual memiliki distribusi normal. Jika nilai 
residual tidak mengikuti distribusi normal maka uji statistik menjadi tidak valid untuk jumlah sampel kecil menurut Ghozali (2016;154).

Uji normalitas non-parametik Kolmogorov-Smirov (K-S) merupakan salah satu cara untuk menguji normalitas residual. Uji (K-S) dilakukan dengan membuat hipotesis :

$\mathrm{H}_{0}$ : Jika nilai signifikansi $>0,05$ data residual berdistribusi normal.

$\mathrm{H} \alpha$ : Jika nilai signifikansi $<0,05$ data residual berdistribusi tidak normal.

\subsubsection{Uji Multikolonieritas}

Jika pada model persamaan regresi mengandung gejala multikolinearitas, berarti terjadi korelasi (mendekati sempurna) antar variabel bebas. Model regresi yang baik seharusnya tidak terjadi korelasi antara variabel independen. Suatu model regresi yang bebas multiko adalah sebagai berikut mempunyai nilai tolerance kurang dari 0,10 dan nilai VIF (Variance Inflation Factor) lebih dari 10. (Ghozali, 2016;104).

\subsubsection{Uji Heteroskedastisitas}

Menurut Ghozali (2016:134) uji heterokedastisitas digunakan untuk menguji apakah dalam sebuah model regresi terjadi ketidaksamaan variancedari residualdari satu pengamatan ke pengamatan lain. Jika variancedan residualdari satu pengamatan ke pengamatan yang lain tetap maka disebut homokedastisitas dan jika variance berbeda disebut heterokedastisitas. Model regresi yang baik adalah yang mengguanakan homokedastisitas atau tidak terjadi heteroskedastisitas. Untuk melihat 
adanya heteroskedastisitas dilakukan dengan menggunakan uji statistik. Uji statistik yang dipilih adalah uji glejser, yang meliputi :

1. Apabila sig. 2-tailed $<\alpha=0.05$, maka terjadi heteroskedastisitas.

2. Apabila sig. 2-tailed $>\alpha=0.05$, maka tidak terjadi heteroskedastisitas.

\subsection{Teknik Analisa Data}

Analisis data merupakan suatu keadaan untuk meneliti, memeriksa, mempelajari, membandingkan, data yang ada dan membuat indepretasi yang diperlukan. Selain itu, analisi data dapat digunakan untuk mengidentifikasi ada tidaknya masalah.

\subsubsection{Analisis Tanggapan Responden Antar Variabel Penelitian}

Bagian analisis ini akan membahas mengenai bentuk tanggapan responden terhadap kuesioner yang disebarkan kepada responden. Dari sebaran jawaban responden selanjutnya akan diperoleh satu kecenderungan atas jawaban responden tersebut. Untuk mendapatkan kecenderungan jawaban responden terhadap jawaban masing-masing variabel akan didasarkan pada nilai rata-rata skor yang selanjutnya akan dikonfirmasikan pada tabel interval penelitian. Adapun perhitungan ratarata dari responden menggunakan rumus sebagai berkut :

$$
\mathbf{x}=\frac{\sum X}{\mathbf{N}}
$$

(Sugiyono, 2013)

Keterangan :

X : Angka Rata-rata 
N : Jumlah Skor

$\sum \mathrm{X} \quad$ : Nilai Responden

Hasil rata-rata jawaban responden tersebut dikonfirmasikan pada interval. Rentang interval penelitian tersebut dihitung berdasarkan rumus sebagai berikut (Sugiyono, 2013) :

$$
\mathbf{I}=\frac{\boldsymbol{R}}{\mathbf{K}}
$$

Keterangan :

I : Interval

R : Range (Nilai tertinggi - Nilai terendah)

K : Jumlah Kategori

Setelah besarnya interval diketahui, kemudian dibuat rentang skala hingga dapat ditentukan kriteria penelitian persepsi responden terhadap variabel-variabel penelitian sebagai berikut :

Tabel 3.3

Skala Interval

\begin{tabular}{|c|c|}
\hline Interval Koefisien & Tingkat Hubungan \\
\hline $1,00-1,79$ & Sangat Tidak Baik \\
$1,80-2,59$ & Kurang Baik \\
$2,60-3,39$ & Cukup \\
$3,40-4,19$ & Baik \\
$4,20-5,00$ & Sangat Baik \\
\hline
\end{tabular}

Sumber: (Sugiyono, 2013)

\subsubsection{Regresi Linier Berganda}

Mengacu pada tujuan dan hipotesis penelitian, maka model analisis yang digunakan adalah analisis regresi linier berganda. Penggunaan 
analisis ini dengan alasan untuk mengetahui hubungan antara variabel bebas dengan variabel terikat, yaitu Reward $\left(\mathrm{X}_{1}\right)$, Punishment $\left(\mathrm{X}_{2}\right)$ terhadap Kinerja Karyawan (Y). Menurut Sugiyono (2017:313) persamaan analisis regresi linier berganda dapat dirumuskan sebagai berikut:

$$
\mathbf{Y}=\mathbf{a}+\mathbf{b}_{1} \mathbf{X}_{1}+\mathbf{b}_{2} \mathbf{X}_{2}+\mathbf{e}
$$

Keterangan :

Y : $\quad$ Variabel Kinerja

a : Constanta

$\mathrm{b}_{1} \quad$ : Koefisien regresi antara reward dengan kinerja

$\mathrm{b}_{2} \quad: \quad$ Koefisien regresi antara punishment dengan Kinerja

$\mathrm{X}_{1} \quad: \quad$ Variabel reward

$\mathrm{X}_{2} \quad: \quad$ Variabel punishment

e : $\quad$ Error

\subsubsection{Uji Determinasi $\left(\mathbf{R}^{2}\right)$}

Koefisien determinasi $\left(\mathrm{R}^{2}\right)$ bertujuan mengukur kemampuan model dalam menerangkan variasi variabel terkait dengan nilai antara nol dan nilai satu. Nilai $\mathrm{R}^{2}=0$ berarti variabel bebas tidak memiliki kemampuan dalam menjelaskan variasi variabel terkait dan nilai $\mathrm{R}^{2}=1$ berarti variabel bebas memiliki kemampuan dalam menjelaskan variasi variabel terkait.

Menurut sugiyono (Sugiyono, 2013: 260) analisis koefisien determinasi dapat dirumuskan sebagai berikut:

$$
K D=\mathbf{r}^{2} \times 100 \%
$$


Keterangan :

KD : Koefisien determinasi

$\mathrm{r}^{2} \quad$ : Koefisien korelasi yang dikuadratkan

Kriteria untuk analisis koefisien determinasi adalah:

1. Jika Kd mendeteksi nol (0), maka pengaruh variabel independent terhadap variabel dependent lemah.

2. Jika Kd mendeteksi satu (1), maka pengaruh variabel independent terhadap variabel dependent kuat.

\subsection{Uji Hipotesis}

Penelitian ini juga mengunakan uji hipotesis. Data diperoleh dari hasil pengumpulan data di atas dapat diperoses sesuai dengan jenis data kemudia disajikan dalam bentu tabel dan angka metode statistik seagai berikut:

\subsubsection{Uji T (Uji Parsial)}

Pengujian yang dilakukan adalah uji parameter (uji korelasi) dengan menggunakan uji t-statistik. Hal ini membutikan apakah terdapat pengaruh antara masing - masing variabel independen $(\mathrm{X})$ dan variabel dependen (Y). Menurut Sugiyono (2013:250) menggunakan rumus:

$$
\mathbf{t}=\frac{r \sqrt{n-2}}{\sqrt{1-r^{2}}}
$$

Keterangan:

$\mathrm{t}=$ Nilai uji $t$

$\mathrm{r}=$ Koefisien korelasi pearson 
$\mathrm{r}^{2}=$ Koefisien determinasi

$\mathrm{n}=$ Jumlah sampel

Jika hasil pengujian ini selanjutnya dibandingkan dengan $t_{\text {tabel }}$ dengan menggunakan tingkat kesalahan 0,05 uji dua pihak dan $d b=\mathrm{n}-2$, kriteria sebagai berikut:

- $\mathrm{H}_{0}$ diterima bila $\mathrm{t}_{\text {hitung }}<\mathrm{t}$ tabel

- $\mathrm{H}_{0}$ diterima bila $\mathrm{t}_{\text {hitung }}>\mathrm{t}$ tabel

Jika pengujian statastik menunjukan $\mathrm{H}_{0}$ tolak, maka berarti variabel - variabel independen secara parsial mempunyai pengaruh yang signifikan terhadap kualitas kinerja karyawan. dalam pengujian hipotesis ini, penulis menggunakan uji siginifikan atau uji parameter $r$, maksudnya untuk menguji tingkat signifikan maka harus dilakukan pengujian parameter $r$. Dengan langkah pengujian sebagai berikut :

a. Perumusan Hipotesis

$\mathrm{H}_{0}$ : Reward $\left(\mathrm{X}_{1}\right)$ dan Punishement $\left(\mathrm{X}_{2}\right)$ tidak berpengaruh signifikan secara persial terhadap Kinerja Karyawan (Y) pada PT. Sandabi Indah Lestari Bengkulu Utara.

$\mathrm{H}_{\alpha}$ : Pemberian Reward $\left(\mathrm{X}_{1}\right)$ dan Punishement $\left(\mathrm{X}_{2}\right)$ mempunyai pengaruh signifikan secara persial terhadap Kinerja Karyawan (Y) pada PT. Sandabi Indah Lestari Bengkulu Utara.

b. Kriteria Pengujian

1. Jika $\mathrm{t}_{\mathrm{sign}}<(\alpha=0,05) \mathrm{H}_{0}$ ditolak, $\mathrm{H}_{\mathrm{a}}$ diterima. Artinya secara parsial ada pengaruh signifikan variabel Pemberian Reward $\left(\mathrm{X}_{1}\right)$ dan 
Punishement $\left(\mathrm{X}_{2}\right)$ terhadap Kinerja Karyawan (Y) pada PT. Sandabi Indah Lestari Bengkulu Utara.

2. Jika $t_{\text {sign }}>(\alpha=0,05) \mathrm{H}_{0}$ diterima, $\mathrm{H} \alpha$ ditolak. Artinya secara parsial tidak ada pengaruh signifikan variabel Pemberian Reward $\left(\mathrm{X}_{1}\right)$ dan Punishement $\left(\mathrm{X}_{2}\right)$ Kinerja Karyawan (Y) pada PT. Sandabi Indah Lestari Bengkulu Utara.

Nilai $t_{\text {sign }}$ dari uji $\mathrm{t}$ dapat dilihat dari hasil pengelolaan dari program SPSS for Windows versi 16.0

\subsubsection{Uji F (Uji Simultan)}

Pengujian yang dilakukan ini adalah dengan uji parameter $\beta$ (uji korelasi) dengan menggunakan uji F-statistik. Untukmenguji pengaruh variabel bebas secara bersama-sama (simultan) terhadap variabel terikat digunakan uji F. Menurut Sugiyono (2013:257) dirumuskan sebagai berikut:

$$
F_{\mathrm{h}}=\frac{R^{2} / K}{\left.\left(1-R^{2}\right) / N-K-1\right)}
$$

$$
\begin{aligned}
& \text { Keterangan : } \\
& F_{\mathrm{h}} \quad=\text { Nilai uji } F \\
& \mathrm{R}^{2} \quad=\text { Koefisien korelasi bergadang } \\
& \mathrm{K} \quad=\text { Jumlah variabel independen } \\
& \mathrm{n} \quad=\text { Jumlah anggota sampel }
\end{aligned}
$$

Distribusi $F$ ini ditentukan oleh derajat kebebasan pembilang dan penyebut yaitu $\mathrm{k}$ dan $\mathrm{n}-\mathrm{k}-1$ dengan menggunakan tingkat kesalahan 0,05, untuk uji $F$, kriteria adalah : 
- $\mathrm{H}_{0}$ diterima bila $F_{\text {hitung }}<F_{\text {tabel }}$

- $\mathrm{H}_{0}$ diterima bila $F_{\text {hitung }}>F_{\text {tabel }}$

Bila $\mathrm{H}_{0}$ diterima, maka dapat diartikan bahwa signifikannya suatu pengaruh dari variabel - variabel independen secara bersama - sama atas suatu variabel dependen dan penolakan $\mathrm{H}_{0}$ menunjukkan adanya pengaruh yang signifikan dari variabel - variabel independen yang secara bersama - sama terhadap suatu variabel dependen.

Adapun prosedur pengujian hipotesis statistiknya adalah sebagai berikut:

a. Perumusan Hipotesis

$\mathrm{H}_{0}$ : Tidak ada pengaruh yang signifikan secara bersama-sama antara Reward $\left(\mathrm{X}_{1}\right)$ dan Punishement $\left(\mathrm{X}_{2}\right)$ terhadap Kinerja Karyawan (Y) pada PT. Sandabi Indah Lestari Bengkulu Utara.

$\mathrm{H} \alpha$ : Ada pengaruh yang signifikan secara bersama-sama antara Reward $\left(\mathrm{X}_{1}\right)$ dan Punishement $\left(\mathrm{X}_{2}\right)$ terhadap Kinerja Karyawan $(\mathrm{Y})$ pada PT. Sandabi Indah Lestari Bengkulu Utara.

b. Kriteria Pengujian

Selanjutnya hasil hipotesis di uji dengan ketentuan sebagai berikut :

1. Jika $\mathrm{f}<(\alpha=0,05) \mathrm{H}_{0}$ ditolak, $\mathrm{H} \alpha$ diterima berarti secara bersamaan ada pengaruh Pemberian Reward $\left(\mathrm{X}_{1}\right)$ dan Punishement $\left(\mathrm{X}_{2}\right)$ terhadap Kinerja Karyawan (Y) pada PT. Sandabi Indah Lestari Bengkulu Utara.

2. Jika $\mathrm{f}>(\alpha=0,05) \mathrm{H}_{0}$ diterima, $\mathrm{H} \alpha$ ditolak berarti tidak ada pengaruh secara bersamaan variabel Pemberian Reward $\left(\mathrm{X}_{1}\right)$ dan Punishement 
$\left(\mathrm{X}_{2}\right)$ terhadap Kinerja Karyawan (Y) pada PT. Sandabi Indah Lestari Bengkulu Utara.

Nilai $\mathrm{f}_{\text {sign }}$ dari uji $\mathrm{F}$ dapat dilihat dari hasil pengelolaan dari program SPSS for Windows versi 16.0

\section{DAFTAR PUSTAKA}

Anjani, R. (2019). Tata Kelola Adminitrasi Keuangan, Dan Pembangunan Desa Tepi Laut Kabupaten Bengkulu Utara. Jurnal Pengabdian Masyarakat Bumi Raflesia, 2 (2).

Anwar Prabu Mangkunegara. 2015. Sumber Daya Manusia Perusahaan. Cetakan kedua belas. Remaja Rosda karya: Bandung

Anwar Prabu Mangkunegara, 2013, Manajemen Sumber Daya Manusia Perusahaan. Bandung: PT. Remaja Rosda Karya

Asmawi, M. (2017). The Effect Of Compensation, Empowerment, And Job Satisfaction On Employee Loyalty. International Journal of Scientific Research and Management, 5(12), 7590-7599.

Bangun, Wilson. 2013. Manajemen Sumber Daya Manusia. Jakarta : Erlangga.

Fahmi, Irham. 2016. Manajemen Sumber Daya Manusia Teori dan Aplikasi. Bandung: Alfabeta

Gayatri, G. D. (2020). Pengaruh Pemberdayaan Dan Self Efficacy Terhadap Kinerja Karyawan Bagian Pemasaran (PT. Mayora Kota Bengkulu). (JEMS) Jurnal Entrepreneur dan Manajemen Sains, 1(1).

Gibson, M. 2008. Manajemen Sumber Daya Manusia. Cetakan ke dua. Jakarta: Erlangga

Hasibuan, Malayu S.P, 2004, Manajemen. Edisi Revisi, Penerbit PT. Bumi Aksara, Jakarta

Juita, R. (2020). Manajemen Sdm Global (No. 7n9ds). Center for Open Science.

Irmayanti, Ade. 2013. Penghargaan (Reward)dan Hukuman (Punishment) dalam Organisasi.

Kadarisman, M. 201. Manajemen kompensasi. Jakarta: Rajawali pers 
Mahmudi 2013. Manajemen Sektor Publik. Edisi kedua UPP STIM YKPN, Yogyakarta

Moeheriono. 2014. Pengukuran Kinerja Berbasis Kompetensi, Edisi Revisi. Jakarta: Rajawali

Onsardi, O. (2018). Loyalitas Karyawan pada Universitas Swasta di Kota Bengkulu. COSTING: Journal of Economic, Bussines and Accounting, 2(1), 1-13.

Onsardi, O. (2019). Effect Of Empowerment On Employees Performance (No. v7g9t). Center for Open Science.

Onsardi, O. (2020). Manajemen Sumber Daya Manusia (No. yq85t). Center for Open Science.

Rivai, Veithzal dan Sagala, Ella Jauvani. 2011. Manajemen Sumber Daya Manusia untuk Perusahaan dari Teori ke Praktik. Jakarta: PT Raja Grafindo

Sedarmayanti.2017. Perencanaan dan Pengembangan Sumber Daya Manusia. Bandung: PT Refika Aditama

Siagian, 2006. Teori Reward dan Punishment. Paper Academia. Diakses 13 Maret 2015. Hal 1-32.

Sudarmanto, 2009. Kinerja dan Pengembangan Kompetensi SDM, Yogyakarta: Pustaka Pelajar.

Sugiyono, 2009, Metode Penelitian Kuantitatif, Kualitatif dan R\&D, Bandung : Alfabeta.

Sugiyono. 2010. Metode Penelitian Pendidikan Pendekatan Kuantitatif, kualitatif, dan $\boldsymbol{R} \& \boldsymbol{D}$. Bandung: Alfabeta

Sugiyono. 2013. Metode Penelitian Pendidikan Pendekatan Kuantitatif, Kualitatif, dan $R \& D$. Bandung: Alfabeta.

Sugiyono. (2017). Metode Penelitian Kuantitatif, Kualitatif, dan R\&D. Bandung : Alfabeta, CV.

Wibowo, 2016. Manajemen Kinerja, Edisi Kelima, PT. Rajagrafindo Persada Jakarta 14240.

Veithzal Rivai. 2014. Manajemen Sumber Daya Manusia untuk Perusahaan, Edisi ke 6, PT. Raja Grafindo Persada, Depok, 16956.

Veithzal Rivai Zainal, S. 2015. Manajemen Sumber Daya Manusia Untuk Perusahaan . Edisike-7. Depok: PT RAJA GRAFINDO. 
